\title{
Coups, Corporations, and Classified Information
}

\author{
Arindrajit Dube*, Ethan Kaplan† and Suresh Naidu ${ }^{\mathbb{8}}$ \\ UC Berkeley; IIES, Stockholm University; Harvard University
}

September 19, 2008

\begin{abstract}
We estimate the impact of coups and top-secret coup authorizations on asset prices of partially nationalized US companies that stood to benefit from US backed coups. A small number of highly exposed and well connected firms reacted to coup authorizations classified as top-secret. The average abnormal return to a coup authorization is $1.7 \%$ over 4 days, rising to $3.4 \%$ over thirteen days. Pre-coup authorizations account for a larger share of stock price increases than the actual coup events themselves. There is no effect in the case of the widely publicized, poorly executed Bay of Pigs invasion, consistent with abnormal returns to coup authorizations reflecting credible private information. We also introduce two new intuitive and easy to implement nonparametric tests that do not rely on asymptotic sample size approximations.
\end{abstract}

*adube@berkeley.edu

$\dagger$ †ekaplan@iies.su.se

${ }^{\ddagger}$ snaidu@econ.berkeley.edu

$\S$ We would like to thank Zihe Liu and Ettore Panetti for excellent research assistance. Stefano Della Vigna, Robert Gibbs, John Prados, Gerard Roland and seminar participants at NYU, the Santa FE Institute, UC Berkeley, and the University of Warwick all provided helpful comments. 


\section{Introduction}

This paper estimates the effect of secret United States decisions to overthrow foreign governments on the stock market prices of well-connected companies that stood to benefit from regime change. We look at companies that had a large fraction of their assets expropriated by a government that was subsequently a target of a U.S. sponsored covert operation aimed at overthrowing the regime. We find statistically

and economically significant effects on stock prices both from the regime change itself and from "top secret" authorizations.

Using official timelines reconstructed from CIA documents, we estimate the impact of key decisions concerning coup planning on stock returns. In particular, we find a strong impact on stock prices in a limited number of companies which were both (1.) highly exposed in the country under consideration and (2.) well connected to the CIA. Our results are evidence of two distinct phenomena. First, we provide indirect evidence of organizational leaks from the CIA and/or other parts of the executive branch to financial markets. Secondly, we provide evidence that covert interventions provided arbitrage opportunities for traders of companies connected to the CIA, implying that the coups were valuable to those corporations.

Our findings complement other evidence in empirical political economy that large, politically connected firms benefitted from favorable political regimes (Faccio, 2006; Fisman, 2001; Jayachandran, 2006; Knight, 2006; Snowberg et al., 2007). However, we show that firms benefit not only from publicly announced events but also from top-secret events, suggesting information flows from covert operations into markets. Our results are consistent with recent papers that have used asset price data to show that companies can profit from conflict (DellaVigna and La Ferrara, 2007; Guidolin and La Ferrara, 2007). We also provide evidence that private information leaks into asset prices slowly over time. This is consistent with both private information theories of asset price determination (Allen et al., 2006) and the empirical literature on insider trading (Meulbroek, 1992). 
Additionally, we interpret our results as providing an estimate of the value of a coup to a potential corporate beneficiary. Net total price rises from coup authorizations are larger in magnitude than price changes from the coups themselves. There exists widespread scholarly disagreement on the motivations behind covert interventions, ranging from ideological motives (Westad, 2005) to protecting the economic interests of powerful lobbies in the intervening governments (Gibbs, 1991). While we are unable to resolve this debate, we show that regime changes lead to significant economic gains for corporations that stood to benefit from U.S. interventions in developing countries.

Within economics, the literature on anti-democratic political transitions has emphasized the role of domestic elites (Acemoglu and Robinson, 2006). However, coups have often been instigated, planned and even partially executed from abroad, most notably by the U.S. and the Soviet Union during the Cold War. Operating under the threat of nuclear war, direct conflict between the two superpowers was replaced by covert and proxy operations to install supporting regimes. According to Easterly et al. (2008), 24 country leaders were installed by the CIA and 16 by the KGB since the end of the Second World War.

Our paper also makes an econometric contribution to hypothesis testing in event studies. The structure of our event study allows us to improve on existing nonparametric tests. Nonparametric tests used in event studies do not use exact small sample distributions but rather distributions with faster asymptotic convergence to a normal distribution (Campbell et al., 1997; Guidolin and La Ferrara, 2007). We introduce two new small sample tests that are valid without asymptotic approximations based upon the number of events.

Section II of this paper discusses the history of U.S. covert interventions, with backgrounds on each of the coups in our sample. Section III describes the data and our selection of companies and events. Section IV outlines our estimation strategies and Section $\mathrm{V}$ reports our main results along with a number of robustness checks. In section VI, we present and implement our small sample tests. Section VII provides 
an interpretation of our main results; we decompose the total value of a coup to a multinational into public and private components. We also calibrate a simple asset pricing equation and back out the implied changes in the stock market's assessment of the probability of a future coup. We conclude in section VIII.

\section{Background and History: The CIA}

The Central Intelligence Agency was brought into existence in 1947 under the National Security Act of July 26. The act allowed for "functions and duties related to intelligence affecting the national security", in addition to intelligence gathering (Weiner, 2007). Initially, the scope of the CIA was relegated to intelligence, though a substantial and vocal group advocated for a more active role for the agency. Most of the CIA's legal authority derived from National Security Council Directive No. 4, which ordered the CIA to undertake covert actions against communism.

Covert operations designed to overthrow foreign governments necessitated the approval of the director of the CIA in addition to the President of the United States. A 1978 executive order described covert actions as "operations conducted abroad in support of national foreign policy objectives which are designed to further official United States programs and policies abroad and which are planned and executed so that the role of the United States government is not apparent or acknowledged publicly" (Johnson, 1989).

After Eisenhower's election in 1952, Allen Dulles was appointed director of the agency. Under Dulles, the CIA expanded its role to include planning and executing overthrows of foreign governments using military force. All but 5 of the CIA operations in Table I, including 3 of the 4 studied in this paper, began during Dulles' reign as CIA director under the Eisenhower administration. Allen Dulles was supported by his brother, John Foster Dulles, who was the contemporaneous Secretary of State. The Dulles brothers together wielded substantial influence over American foreign policy from 1952 to 1960. 
The qualitative evidence suggesting links between U.S. finance and the CIA is substantial. Firstly, the Dulles brothers both worked for Sullivan and Cromwell, a prominent Wall Street law firm that included, for example, United Fruit in its clientele. Secondly, much of the CIA, particularly under Dulles, was extracted from law firms close to the financial sector. For example, Frank Wisner, who was in charge of the covert operations wing of the CIA(called the Office of Policy Coordination(OPC)), worked for the Wall Street law firm Carter Ledyard prior to joining the OPC. "Wisner, in turn, recruited Barnes and Fitzgerald, both Harvard-trained Wall Street lawyers" (Thomas, 1996). In addition, CIA leadership would often consult with corporations that had investments in countries of interest to the CIA. We exploit declassified records of these meetings in determining our set of companies with access to the CIA below.

In 1974, partly due to public outcry over the U.S. involvement in the military coup in Chile, the Hughes-Ryan Act increased congressional oversight of CIA covert operations. In 1975, the U.S. legislature formed subcommittees to investigate American covert action. Thus, the intensity and scope of U.S. covert actions fell substantially (Johnson, 1989). The height of covert CIA activity lasted slightly more than twenty years encompassing the period from 1952 to 1974.

Our sample of coups includes 4 such covert attempts. The first one occurred in Iran in August, 1953, when the CIA, assisted by the UK MI6, engineered a toppling of Prime Minister Mossadegh. Mossadegh had nationalized the oil fields and refinery at Abadan, which were the property of the Anglo-Iranian oil company, itself a nationally owned company of the UK government. In Guatemala, the CIA overthrow of Jacobo Arbenz Guzman in June, 1954 occurred after the Arbenz government had nationalized most of United Fruit's assets in Guatemala. In Cuba, the Castro government nationalized all US property in 1960, one year before the failed Bay of Pigs coup attempt in April, 1961. Finally, the Chilean nationalization of copper and other foreign owned assets began under the Frei government but accelerated after the Allende government came to power in late 1970. Allende was in office less than 3 years before he was killed in a coup on September 11, 1973. In appendix A, we provide a more 
detailed synopsis of each coup, focusing on the nature of the pre-coup regime, the motivations behind the expropriations, the American response, and the resolution of the coup.

\section{Data}

\subsection{Coup Selection}

We selected our sample of coups on the following basis: (1.) a CIA timeline of events or a secondary timeline based upon an original CIA document existed, (2.) the coup contained secret planning events including at least one covert authorization of a coup attempt by a national intelligence agency and/or a head of state, and (3.) the coup authorization was against a government which nationalized property of at least one sufficiently exposed multinational firm with publicly traded shares. Table I shows a full list of CIA operations from Prados (2006). The highlighted operations are those that met our criteria, which limited us to 4 coup attempts. Operation Ajax in Iran in 1953 led to the overthrow of Muhammed Mossadegh. Operations PBFortune and PBSuccess in Guatemala in 1952 and 1954 respectively culminated in the overthrow Jacobo Arbenz Guzman. The US unsuccessfully attempted to overthrow the Fidel Castro government in Operation Zapata in 1961. Finally, Operation FU/Belt in Chile, which began in 1970, contributed to the overthrow of Salvador Allende.

\subsection{Event Selection}

Our primary source of events are timelines reconstructed directly from declassified CIA sources by official historians. Operation Ajax in Iran was constructed by the New York Times on the basis of the internal CIA history of the Iran operation written by Wilber $(1954)^{1}$ and declassified in $2000^{2}$. In the case of Guatemala, the CIA itself did

\footnotetext{
${ }^{1}$ Available at http://www.gwu.edu/ nsarchiv/NSAEBB/NSAEBB28/

${ }^{2}$ Available at http://www.nytimes.com/library/world/mideast/041600iran-cia-index. html
} 
an internal timeline of the operation, which we used ${ }^{3}$. The Bay of Pigs timeline $e^{4}$ comes from the National Security Archives, housed at George Washington University, which has filed virtually all of the Freedom of Information Act (declassication) requests regarding Cuba and the CIA. For FU/Belt in Chile, we used the timeline constructed by the Church Committee which was a committee set up in 1975 by the US Senate to investigate foreign intelligence operations ${ }^{5}$. The Church Committee Report, which was recently declassified, created a timeline of events based upon top-secret CIA documents for Chile.

We first extract all of the authorization events from the official timelines. These are restricted to those where either the coup was explicitly approved by the head of a government (the President of the United States or the Prime Minister of the United Kingdom) or the head of an intelligence agency (the CIA or MI6) or where US $\$ 1$ million or more were allocated to the overthrow of a foreign government. Authorization events are coded as "good" or "bad" depending on whether they increase or decrease the likelihood of a coup. Our selection and coding of authorization events is presented in Table III.

We also extract public events from the official timelines for use as controls in some specifications. Public events are restricted to dates where company assets are nationalized or regime transitions and consolidations occur. The public events are coded as "good" or "bad", where "good" events are those which are likely to increase the stock price and "bad" events are ones which are likely to cause a decline in the stock price. The public events and their coding is listed in Table IVA; Table IVB lists the dates of the regime changes themselves.

\footnotetext{
${ }^{3}$ Available at http://www.gwu. edu/ nsarchiv/NSAEBB/NSAEBB4/

${ }^{4}$ Available at http://www.gwu.edu/ nsarchiv/bayof pigs/chron.html

${ }^{5}$ Available at http://foia.state.gov/Reports/ChurchReport.asp
} 


\subsection{Company Selection}

We apply 3 criteria to select our sample of companies. First, a company must be publicly traded, so that we can observe a stock price. Secondly, the company must be "well-connected", in terms of being linked to the CIA. Finally, the company should be highly exposed to political changes in the affected country, in the sense that a large fraction of a company's assets are in that country.

We begin with the list of all companies nationalized by a regime prior to the coup, which we obtain from the CIA timelines. In the cases of Chile and Cuba, the nationalized companies nationalized are not mentioned by name in the timelines themselves. We obtain lists of nationalized copmanies in Chilea and Cuba lists of nationalized companies from Congressional testimonies about expropriations of U.S. companies. First, we require that the company was listed on the NYSE, NASDAQ, or AMEX exchanges, which we determine from listing in the CRSP database. Second, we determine, from declassified sources, whether or not the company had met with the CIA. We first include all companies that were listed as having met with the CIA in the internal histories. Then we do automated searches of the declassified CIA documents in the National Security Archive for CIA memos mentioning the company and the country in the period of the CIA operation. If a company is listed together with the country in a declassified memo, it is included in the sample. Finally, we calculate the percent of a company's assets that were in the country, which we call a company's exposure, for the remaining companies. In our benchmark specification, we include only those companies which had the highest exposure for each country.

For example, ITT met with CIA officials about Chile. However, ITT's assets in Chile were only $7.3 \%$ of its total assets (Table II) and thus it would be difficult to pick up the impact of even a large change in the probability of a coup. Its stock price does not seem to have reacted to coup authorizations. Alternatively, Anglo-Lautaro Nitrate Ltd. was a small publicly traded company with a majority of its assets in Chile (Table II). However, it did not meet with the CIA and was almost surely not privy to information about coup authorizations. 
In our robustness section, we consider two alternative selections of companies. First, we consider the top 10 most exposed, in total assets rather than percentage terms. In Guatemala and Iran, only one company was effected. In Chile and Cuba, only some are publicly traded and thus available on CRSP. In total, this specification adds 9 companies, all of which are listed in Table II. Second, we consider country portfolios of all companies which were listed as having met with the CIA and which had over $15 \%$ of their assets. In comparison with our baseline where we consider the most exposed connected company in the nationalizing country, this specification adds only one company, ITT in Cuba.

\section{Methodology}

Our main hypothesis is that authorization events should result in a slow increase in the stock price of the affected company over the days following the event. There are multiple reasons that prices may react steadily and slowly as opposed to all at once with private information. First, the information may itself slowly take time to diffuse. Second, there may be secondary trading or momentum; traders may update based upon previous price increases. Third, traders may be cautious and wait to see if other investors are trading on the private information (Allen et. al., 2006). For this reason we look at windows of different lengths around the authorization events. Our benchmark specification is a 4 day window starting at the event date.

In this paper, we employ two different estimation strategies. The first, which we call the "regression method", includes the contemporaneous market return as a control along with dummies for contemporaneous authorization events in a single specification where the dependent variable is the raw stock return. Our second approach is the event-study methodology originally developed by Fama (Campbell et al., 1997; Fama, 1969). We first estimate abnormal returns using a pre-event sample, where abnormal returns are returns in excess of what would be predicted in a simple linear market

model. We then calculate the mean cumulative abnormal returns for a number of 
days after each event, and test to see if it significantly different from 0 . We refer to the second approach as the "out of sample method", referring to the fact that the abnormal returns are calculated using a sample of stock market returns from before the authorization events.

\subsection{Regression Method}

For the regression method we estimate the following equation with OLS:

$$
R_{f t}=\alpha_{f}+\beta_{f} R_{m t}+\gamma D_{f t}+\epsilon_{f t}
$$

$R_{f t}$ is the one day raw stock return for firm $f$ between date $t$ and date $t-1, R_{m t}$ is the one day New York Stock Exchange index return between date $t$ and date $t-1$, and $D_{f t}$ is a $k$-day dummy variable which takes on a value of one on an authorization day and for the $k-1$ days following an authorization day. The average daily abnormal return over the $k$ days after an event (inclusive) is $\gamma$. The cumulative abnormal return is $k \gamma$, the average abnormal return times the event window length. Our sample is the time period starting exactly one year before the nationalizing regime comes to power until exactly one year after the end of the coup. The standard error for the cumulative abnormal return is given by the standard error on the regression coefficient multiplied by the length of the window. Except where noted, we report heteroskedasticity-robust standard errors.

\subsection{Out of Sample Method}

The out of sample method first estimates a market model in an "estimation window" that is prior to any coup-related events. Our estimation window is one calendar year in length and begins 2 years before the nationalizing regime comes to power. ${ }^{6}$ For

\footnotetext{
${ }^{6}$ The number of trading days differ in the estimation window. Chile has 235 days; Cuba has 250 days; Guatemala has 282 days; and Iran has 260 days. Guatemala has more trading days because the NYSE was open on Saturdays until September 29, 1952. Also since more trading holidays have
} 
each firm, we estimate:

$$
R_{f t}=\alpha_{f}+\beta_{f} R_{m t}+\epsilon_{f t}
$$

Using the estimated coefficients from (2), we calculate the abnormal returns around our authorization events as the difference between the actual and predicted returns for a given date:

$$
A \hat{R}_{f t}=R_{f t}-\hat{a}_{f}-\hat{\beta}_{f} R_{m t}
$$

We consider windows around the authorization events of length $k$, where $k$ is between 0 and 15 days. We take the average abnormal return over the $k$ days as:

$$
\frac{\sum_{t=t_{0}}^{t_{0}+k} A \hat{R}_{f t}}{k+1}
$$

The cumulative abnormal return for $k+1$ days for firm $f, C A R(f, k+1)$, is defined as:

$$
C A R(f, k+1)=\sum_{t=t_{0}}^{t_{0}+k} A \hat{R}_{f t}
$$

The standard error for the average abnormal return for an individual event is the estimated standard deviation from the estimation window multiplied by the square root of the length of the CAR period:

$$
\sigma_{\hat{A} R_{f}} \sqrt{k+1}
$$

To compute cumulative abnormal returns for multiple events, we add up the CARs across events. In most event studies, there is one event per firm. In our setup, that is not the case. However, as long as our events are independent over time within firm

been added over time, the number of trading days per year has decreased over time. Lastly, AngloIranian traded on the London Stock Exchange during the period in question, which accounts for the lower number of trading days in comparison with Guatemala. We opted to use exactly one year for the estimation window rather than a fixed number of trading days. However, the choice of the estimation window does not impact our results. 
as well as across firms, we can use abuse notation use and $f$ to index events over a set $F$ of events with $|F|$ number of events. In this case, different events may correspond to the same firm. Then, we can compute the CAR for a group of firms:

$$
C A R(F, k+1)=\frac{\sum_{f=1}^{|F|} \sum_{t=t_{0}}^{t_{0}+k} A \hat{R}_{f t}}{|F|}
$$

and we can compute the standard error by:

$$
\frac{\sum_{f=1}^{|F|} \sigma_{\hat{A} R_{f}} \sqrt{k+1}}{|F|}
$$

\section{Results}

\subsection{Baseline Results}

In Table 5, we report the cumulative abnormal returns for authorization events using window lengths ranging 1 to 16 days. We find clear evidence that stock prices react positively to authorization events using both our regression and out of sample methods. In the pooled sample, the average 4 day stock price return for an authorization event is $1.7 \%$ with a standard error of $0.7 \%$. The cumulative abnormal returns are significant for the all-country sample from 4 day through 16 day cumulative abnormal returns at a minimum of $10 \%$ level of significance and often at a $1 \%$ level, depending upon the specification. The abnormal returns are largest between 3 and 12 days after the event, consistent with the hypothesis that private information is incorporated into asset prices with a delay.

Figure 1 provides graphical evidence on abnormal returns around an authorization event, with $95 \%$ confidence intervals shown. We compute cumulative abnormal returns, aggregated across events, for each of the 22 days following an event and each of the 22 days prior to an event, aggregated backwards in time. Cumulative abnormal returns become significant at a $5 \%$ level on the 4 th day after an event and remain 
significant until day 13. Moreover, the gains seem to be permanent, although not statistically distinguishable from 0 after approximately 2 weeks. Going backwards in time from the event date, however, the cumulative abnormal returns show no trends and are never significant.

The effects for Iran and Guatemala are consistently the strongest. In both cases, the average cumulative abnormal return after 4 days is around $2.5 \%$ with a standard error of less than $0.9 \%$ using the regression method. The out of sample method's estimates are almost identical for Guatemala and smaller for Iran. The standard errors are consistently smaller using the out of sample method. The Chile estimates are slightly smaller in magnitude. The peak effect is almost $0.5 \%$ per day over a 4 day horizon. The abnormal returns for Guatemala and Iran are $0.5-0.6 \%$ per day by the day after the event and they remain that high for the first 6 days.

We do not find an effect within the Cuba subsample. There is no detectable change in the stock prices of affected companies following a decision to invade Cuba, whether made by the CIA or the President. This could in part be due to the poor planning and execution of Operation Zapata. Much of the information was leaked to the press ahead of time ${ }^{7}$. Additionally, substantial errors in the Bay of Pigs planning and implementation may have made investors rightfully skeptical about the likely success of the operation.

\subsection{Robustness}

We perform a number of robustness checks. All are estimated both in the pooled sample and by country. We compute cumulative abnormal returns over a 4 day period following an authorization event. All specifications are estimated using the regression method.

\footnotetext{
7 "Kennedy reads the [NYT] story he exclaims that Castro doesn't need spies in the United States; all he has to do is read the newspaper" (Wyden, 1979)
} 


\subsubsection{Public Events and Media Coverage}

Top-secret decisions to overthrow foreign governments may have coincided with public events in the targeted countries. This could bias our estimates, reflecting the effect of public news rather than private information. We control for other events in two different ways. First, we control for the number of articles in the NY Times mentioning the country by name. Second, we control for other public events; these are nationalizations of foreign owned property as well as electoral transitions and consolidations which are also listed in the declassified timelines. They are listed in Table IVA. Third, we control simultaneously for both public events and NY Times articles. Lastly, we also try dropping all dates where the NY times had at least one article on the country (Meulbroek, 1992). This is a strong test. Since most days have at least one article mentioning any given one of our countries, we lose most of our sample in this specification.

Table VI reports 4-day cumulative abnormal returns. We find that controlling for public events and New York Times articles does not affect our results. The average aggregate effect for a 4-day period is between $1.7 \%$ to $2.4 \%$ and significant at the $1 \%$ level, depending on the specification. This is true even when we restrict to days with no New York Times articles about the relevant country. Our results by country are largely similar to those from the baseline specifications. One exception is the estimate for Cuba on the sample restricted to days where the New York Times had no coverage of Cuba. In this case, the coefficient is $1.7 \%$, and significant at the $10 \%$ level. This is consistent with the theory that top-secret news about authorizations is more credible when it remains covert.

\subsubsection{Other Robustness Checks}

We also consider raw returns, unadjusted by a market return, reassuring us that our cumulative abnormal return effects are due to increases in the treatment company stock prices rather than drops in the market. Column 1 of Table VII shows an 
average $0.49 \%$ cumulative abnormal return per day. To control for potential serial correlation in returns, we cluster on month. As can be seen in Column 2 of Table VII, this reduces our standard errors across specifications and does not alter any of our qualitative results.

We control for industry returns by first constructing an equal-weighted basket of returns for all companies in the same 3-digit industry as our treatment companies. We exclude the treatment companies themselves, and otherwise restrict the basket to companies which were listed in CRSP for the entire event window period for the treatment company in question. We then regress the returns of the treatment company on the NYSE index, the authorization events, and the equal weighted industry index. Column 3 of Table VII shows the estimates from this specification, and again the effect is unchanged.

We also consider two placebos, reported in columns 7 and 8 of Table VII. We regress NYSE index returns on our event dummies. We also regress our equal-weighted baskets of industry returns on country-specific NYSE index returns and the authorization event dummies. The 4 day abnormal returns are small and insignificant in all of the samples, both with the NYSE returns as the dependent variable and with the industry returns as the dependent variable.

We consider two other specifications where we look at a broader set of companies, reported in columns 4 and 6 of Table VII. First, we construct an equal-weighted basket of all companies within a country who (1.) met with the CIA and (2.) held $15 \%$ or more of their assets in the nationalizing country. Our results in this specification are similar to our baseline results. This is unsurprising since our sample in this specification is the same as in our baseline with the exception of the addition of ITT to the country portfolio in Cuba. In our second specification, we consider all publicly listed companies in the top ten most exposed companies operating within the nationalizing country. Here we use gross asset exposure rather than exposure as a percentage of total assets. This leaves us with 13 companies in total, listed in Table II. The 4 day abnormal returns for Chile and Cuba are both negative and not significant 
at the $10 \%$ level. This is consistent with the hypothesis that only companies which were both large and highly exposed would react to authorization events.

One potential explanation for our findings is pre-existing market momentum. We include a dummy that is equal to 1 in a 20 day window around each authorization event. This specification tests whether the abnormal returns are higher in the 4 days right after an authorization than in the average of the 20 day period surrounding each authorization event. Column 5 of Table VII shows that the average abnormal return per day is approximately $0.52 \%$ and is significant at the $1 \%$ level. Pre-existing price trends do not explain our results.

\subsection{Time-Shifted Placebos}

As additional evidence that our effects are not an artifact of the data, we rerun our main specification on placebo dates. We take our 4 day cumulative abnormal returns and shift our authorization events forwards as well as backwards by 5, 10, 15, 20 and 30 days. For a $K$ day shift, we estimate:

$$
R_{f t}=\alpha_{f}+\beta_{f} R_{m t}+\gamma_{K} D_{f t+K}+\epsilon_{f t}
$$

Out of the 11 time-shifted regressions, $\gamma_{K}$ is only significant for $K=0$, our benchmark specification with cumulative abnormal return of approximately $1.7 \%$ which is significant at the $1 \%$ level. The cumulative abnormal returns 5 days or 10 days before a authorization event are zero to a tenth of a percentage point. The two largest of the remaining ten abnormal returns are the ones for $K=30$ and $K=5$. Both are between $0.6 \%$ and $0.7 \%$. All other abnormal returns are well below $0.5 \%$. The placebo estimates reinforce that our baseline estimates are due to local serial correlation in returns. The pattern of no abnormal returns before a decision, sizeable abnormal returns just after a decision, and smaller possible abnormal returns in the medium run after a decision is consistent with our hypothesis of secret authorization events causing a slow increase in the stock price. 


\subsection{Coup Effects}

We now estimate abnormal returns, using the regression method, for coup attempts. We do this for two reasons. First, we want to show that these companies were affected by the coup attempts themselves, confirming that companies were benefitting from the regime change. Second, we want to compare the direct effect of the coup itself to the total net rise due to pre-coup authorizations.

We look at 3 specifications: abnormal returns on the first day of the coup, abnormal returns on the first day of the new regime, and abnormal returns during the coup window. We define the coup window as the period from and including the first day of the coup to and including the first day of the new regime. For Cuba, which was unsuccessful, the coup window is the duration of the Bay of Pigs operation, as given in the CIA timeline. These dates are listed in Table IVB.

Since our coup window lengths vary across countries, instead of reporting cumulative abnormal returns, we report the average daily abnormal return during the window. Our results are large and significant. On an average day during the coup window, our treatment companies, experienced a stock price rise of $0.8 \%$. The individual company average abnormal returns vary from United Fruit in Guatemala which had zero rise on average during the coup window to Anaconda in Chile which experienced a 4.6\% increase in its stock price. Anaconda's large increase in its stock price was partially due to the fact that the coup happened quickly and was consolidated essentially immediately; this is different from our 3 other coups where it took longer for the overthrow to succeed or fail. Cuba's abnormal returns were negative because the coup failed. This suggests that the possibility of a coup against the Castro regime in Cuba had already been priced into American Sugar's stock. Anglo-Iranian oil had a large increase over the coup window. It was approximately $1.4 \%$ per day and significant at the $10 \%$ level. The insignificant estimate for Guatemala is perhaps due to the high degree of political uncertainty following the coup. When the Arbenz government finally resigned on June 28, 1954, there was still speculation about whether the coup

would be successful. Also, in the 11 days after the fall of the Arbenz regime, 5 separate 
juntas gained control of the government. Lastly, within two weeks of the end of the Guatemalan coup, the United Fruit Company was hit with a large anti-trust law suit (Gleijeses, 1991).

We consider two other measures of the effect of the coup: the abnormal return on the first trading day of the coup and the abnormal return on the first trading day of the new regime. The average abnormal return across companies on the first day of the coup was approximately $2.3 \%$ and significant at the $1 \%$ level. In both Chile and Cuba, the returns were significant at the $10 \%$ level or higher. The abnormal returns in Cuba were positive, perhaps indicating that markets expected the coup to be successful on the first day. The abnormal returns on the first day following the coup attempt (whether or not it was successful) are large for all companies, with Anglo-Iranian at 2.0\%, American Sugar at -3.3\%, United Fruit at 3.7\% and Anaconda at $4.6 \%$. The CIA-engineered regime changes had a substantial impact on stock prices for the exposed companies in our treatment sample.

\section{Small Sample Distribution Tests}

Conditional distributions of abnormal returns are potentially skewed in small samples, thus distorting test size. In response to this problem, tests have been developed which have better small-sample distribution properties than t-tests of OLS coefficients for event study regressions. The two most common are the sign test and the rank test. Both tests focus on median as opposed to mean returns and thus are more informative in the presence of abnormal return skewness. However, the sign and rank tests are both only asymptotically of correct size.

Guidolin and La Ferrara (2007) provides a more detailed summary of the sign and rank tests. The sign test signs events +1 or -1 depending upon whether the event abnormal returns are above or below median abnormal returns. Thus, for each event, we define $G_{f t}=\mathbf{1}\left(e_{f t}-\operatorname{median}\left(e_{f}^{*}\right)>0\right)$, where $e_{f t}$ is the the cumulative abnormal return during event $t$ in country $f$, and the median is taken over the estimation window. 
Under a null hypothesis that event abnormal returns are identically and independently drawn from the same returns distribution as estimation window returns, the average event sign should not be significantly different from zero. The sigh test divides the average sign across firms of the event date, $\sum G_{f t}$ by the standard deviation of the average signs of the firms over the estimation window. This statistic is given by:

$$
\frac{\sum_{f t} G_{f t_{0}}}{\sqrt{\frac{1}{k} \sum_{t=t_{0}-k}^{t_{0}-1}\left(\sum_{f} G_{f t}\right)^{2}}}
$$

The test is asymptotically distributed according to a unit normal but simulations have shown it to have faster small sample convergence properties to the normal in comparison with standard tests on OLS coefficients.

The rank test assigns a rank to each event abnormal return for a firm relative to its estimation window (a total of $k_{1}(f)-k_{0}(f)+1$ daily abnormal returns), which we denote by $\kappa_{f t}$. Under a null hypothesis that mean event rank is not significantly above or below the median rank in the estimation window, the rank test divides the mean rank for event abnormal returns by the standard deviation of the mean rank across firms over the estimation window.

$$
\frac{\sum_{f}\left(\kappa_{f t_{0}}-\frac{k+1}{2}\right)}{\sqrt{\frac{1}{k} \sum_{t=t_{0}-k}^{t_{0}-1}\left(\sum_{f t} \kappa_{f t}-\frac{k+1}{2}\right)^{2}}}
$$

Again, this ratio is asymptotically normally distributed with rapid small sample convergence properties. The rapidity of small sample convergence is verified through simulations (Corrado and Zivney, 1992).

While the sign and rank tests are a definite improvement over small sample OLS estimates, they have two main drawbacks in the context of the current paper. First, when testing the impact of a single event on multiple companies, it is sensible to control for intra-day correlation in returns across companies. However, when each event occurs on a different day, this is not necessary. Moreover, attempting to do 
so in small samples will incorrectly estimate the standard deviation of the returns. Second, the small sample convergence properties of the sign and rank tests are only verified through simulations and thus the speed of convergence may depend upon the distribution of returns. Since all of our events occur on different days, we do not need to take intra-day covariances across companies into account. This allows us to construct actual small sample tests (as opposed to asymptotic tests). We create a test based upon the binomial distribution to supplant the sign test and a test based upon the uniform distribution to supplant the rank test. We report results both for the 4 company sample and the 3 company sample (excluding American Sugar in Cuba).

\subsection{Generalized Bernoulli Test}

The Bernoulli test is a small sample test corresponding to the sign test which is implementable when events are distributed identically and independetly of one another. In general, we would like to come up with a statistic which computes the probability of observing at least as many abnormal returns above or below the median or, more generally, any given percentile:

$$
P\left(\sum_{f} G_{f}\right) \geq m
$$

In the canonical event study, one event occurs on a given day and a group of firms all experience the event. In this case, it makes sense to assume that there is serial correlation in the event returns. Therefore, we can assymptotically approximate the probability by a normal distribution, incorporating the covariance in returns by implementing the sign test. However, if abnormal returns are distributed identically and independently across time and across events, then we know that the events are distributed exactly according to a Bernoulli distribution and the joint probability of getting $m$ events higher than the $p^{\text {th }}$ percentile is given by the cumulative Bernoulli 
distribution:

$$
F_{M}(m ; p)=1-\sum_{f=m}^{M}\left(\begin{array}{c}
M \\
i
\end{array}\right) p^{i}(1-p)^{M-i}
$$

Without loss of generality, we assume that $p \geq .5$. Then, due to the symmetry of the cumulative Bernoulli distribution, the two-sided probability of getting $m$ or more abnormal returns above the $1-p^{\text {th }}$ percentile or below the $p^{\text {th }}$ percentile is given by

$2 \sum_{i=m}^{M}\left(\begin{array}{c}M \\ i\end{array}\right) p^{i}(1-p)^{M-i}$. This is the p-value of the two-sided generalized Bernoulli test.

\subsection{Uniform Rank Test}

The uniform rank test is a small sample test corresponding to the rank test which is implementable when events are distributed identically and independetly of one another. We would like to come up with a statistic which computes the probability of observing average rank being greater than a given cutoff value:

$$
P\left(\frac{\sum_{f} \kappa_{f t_{0}}}{M}\right) \geq \frac{m}{M}
$$

Again, in a canonical event study, all events happen on the same day and so serial correlation across events is likely present in the event returns. However, we can assymptotically approximate the average rank of the events by a normal distribution, incorporating the covariance in returns by implementing the rank test. If abnormal returns are distributed identically and independently across time and across events, then the events are distributed according to a sum of uniform distributions.

Following the standard rank test (Corrado, 1989; Campbell et al., 1997), we rank each of our events relative to the distribution of abnormal returns in the estimation window. As before, we denote the number of trading days in the estimation window as $k$. Then, the median rank including the event itself is $\frac{k+1}{2}$. We then convert the rank into a percentile. Noting that, for i.i.d. variables, percentile is uniformly distributed (Morris and Shin, 2003), we compute the CDF for the sum of the percentiles of $M$ 
independently and uniformly distributed random variables over the interval $[0,1]$. The probability, given $M$ events, that the mean percentile is below $t$ is given by (Mood, Graybill and Boes, 1974):

$$
F_{M}(t)=\sum_{f=0}^{M}\left(\frac{(-1)^{j}(t-f)^{M} \mathbf{1}(t \geq f)}{f !(M-f) !}\right)
$$

Without loss of generality, we assume that $t \geq .5$ Given symmetry of the cumulative distribution function, the p-value of getting a percentile rank greater than $t$ or less than $t-.5$ is then $2\left(1-F_{M}(t)\right)$.

\subsection{Small Sample Distribution Results}

We compute small sample tests for our benchmark of 4 day returns. We report the Bernoulli Test results in Table X. For Iran, all 3 events have abnormal returns above the median abnormal return and two of the 3 events are above the 90th percentile in abnormal returns. Guatemala is similar with all 4 abnormal returns being above the median and 3 out of 4 being above the 90th percentile in abnormal returns. With Chile, 3 out of 4 are above the median and one out of 4 is above the 90th. Finally, for Cuba, only one out of 3 are above the median and none are above the 90th percentile. The probability of getting 11 out of 14 abnormal returns either all above the median or all below the median (i.e. two-sided test) is $5.74 \%$. If we exclude Cuba, then we have 9 out of 11 above the median with a two-sided p-value of $6.54 \%$. P-values for the 90 th percentile are $0.30 \%$ for the 4 country sample and $0.06 \%$ for the 3 country sample.

We also graph 3 and 4 country Bernoulli Tests at the $50^{\text {th }}, 60^{\text {th }}, 70^{\text {th }}, 80^{\text {th }}$, and $90^{\text {th }}$ percentiles. Graph III reveals that for both the 3 and 4 country sample, the p-values drop as we look at higher percentile returns reflecting that our event return dates are strong outliers. This is especially true for Guatemala and Iran.

We now report results for the uniform rank test which we obtain from Table XI. With 
our 4 country sample, we have 14 events and with our 3 country sample, we have 11 events. The uniform rank test assumes that we are comparing 14 (or 11) draws from a uniform distribution. Actually, however, we do not observe the true percentile of the return but rather we estimate it based upon a sample of estimation window returns drawn from the same uniform distribution. Since our estimation window sample is greater than fifty observations per country, this approximation causes almost no significant distortion in contrast to invoking asymptotic approximations to event return distributions which tend to be much smaller in size.

The mean percentage ranks for both Iran and Guatemala are 0.86. The probability of the mean return being at least at the $86^{\text {th }}$ percentile or at most at the $14^{\text {th }}$ percentile, in the case of Iran which has 3 events, is 3.1\%. The p-value for Guatemala, which has 4 events, is $1.4 \%$. Cuba looks essentially random with a rank of 0.49 percentile and a two-sided p-value of $92.9 \%$. The mean percentage rank for Chile is 0.57 which, given 4 events, yields a p-value of $60.6 \%$. The mean percentile rank for the 14 event

4 country sample is the $70^{\text {th }}$ percentile with a p-value of $0.80 \%$ and the mean rank for the eleven event 3 country sample is the $76^{\text {th }}$ percentile with a p-value of $0.4 \%$. These small sample tests show that our results are robust to assumptions about the distribution of abnormal returns.

\section{$7 \quad$ Interpretations}

In the previous sections, we presented estimates of the average impact of coup authorizations on stock market returns. In this section, we interpret the estimated magnitudes in two ways. First, we compare the magnitude of the total percentage change in the stock price due to authorizations with the percentage change from the coup itself. Second, we fit a simple model of asset price determination with our estimated impact of coup authorizations and back out implied changes in prior market probabilities of the coup attributable to authorization events. 


\subsection{Decomposition}

We use our estimates of authorization events and coup effects to calculate an overall value of the coup to our treatment companies. The results from Cuba in this section should be interpreted with caution, as it is not possible to estimate the value of a failed coup to Cuban companies ${ }^{8}$. This incorporates both the change in the asset prices during the actual coup as well as due to authorization events. If we only look at the stock returns at the time of the coup, we ignore the probability of a coup already embedded in the stock price. Therefore, the change in the value of the company over the coup window is likely to be an underestimate of the value to the company of the coup. We compute the value of the coup to the company by adding the change in the stock price over the coup window to the net changes in the value of the companies from the authorizations. We use the country-specific 12 day cumulative abnormal returns in order to compute the value per authorization for each country. The longer window is used in order to capture the full asset price change due to a leaked authorization. The total rise in the stock price due to authorizations is then just one plus the return to an authorization raised to the power of the net number of events ${ }^{9}$ plus the return over the coup window:

$$
\left(1+R_{C, \text { Auth }}\right)^{N}-1+R_{\text {Coup }}
$$

where $R_{C, \text { Auth }}$ is the thirteen day cumulative abnormal return in country $C, N$ is the net number of authorization events, and $R_{\text {Coup }}$ is the cumulative abnormal return in country $C$ over the coup window ${ }^{10}$.

The results are listed in Table XII. Overall, the total gain from authorizations is $9.7 \%$, and the mean return on the first day of the post-coup regime is $3.4 \%$. It is clear that the majority of the gains from coups $(73.6 \%)$ occurred solely as returns to

\footnotetext{
${ }^{8}$ The price fall over the coup window for Cuba measures the change in priors from the beginning of the coup. We return to this in the next subsection

${ }^{9}$ In Guatemala, one of the events is a deauthorization or a negative event. Therefore, the total number of net events in Guatemala is the number of positive events, 3, minus the negative event, which results in 2 net events.

${ }^{10}$ We also tried decomposing the aggregated coup returns using 4-day returns as well as 7-day returns. Even using 4-day returns, net stock price changes from pre-coup authorizations were greater in magnitude than coup events themselves in all countries except for Cuba.
} 
ex-ante authorization events. By country, the total gain from authorizations alone ranges from $6.3 \%$ in Guatemala to $17.1 \%$ in Iran. The return from the coup itself ranges from $3.7 \%$ in Guatemala to $5.8 \%$ in Iran. The total gain from the coup ranges from $10.3 \%$ for Guatemala to $23.9 \%$ in Iran. Note that we use the return on the first day of the new government for Guatemala because, due to the length of the coup and the ensuing political instability after the end of the Arbenz regime, there is no net positive change in the stock price over the exact coup window. We compute that the relative percentage benefit of the coup attributable to ex-ante authorization events ranges from $63 \%$ in Guatemala to $73 \%$ in Chile and $74 \%$ in Iran. In other words, estimating the benefit of the coup simply from looking at the change in the stock price during the coup window leads to a large underestimation of the value to the companies of the coup.

\subsection{Model Simulations}

\subsubsection{Model Setup}

Whereas total abnormal returns from coup authorizations are larger than total returns from the actual coup events, both may represent only a small fraction of coup-related stock price changes. Public events which increase the probability of a coup may account for most of the stock price increases. We construct a simple model of stock market price determination for firms with nationalized assets and a time varying probability of a coup. We use this model to back out the implied changes in the market's subjective probability of a future coup from leaked authorization events.

We assume that investors are risk-neutral, know the exact date of the coup, and share common beliefs at all times about the probability of a successful coup. We consider the asset price of a stock at date $-k: k$ days before the coup attempt. The date of the coup is normalized to date zero. At date $j$, the coup is believed to be successful with

probability $p_{j}$. The rate of time discount is $\beta$. At date $t_{-k}$, the dividend is $(1-e) d$ where $d$ is the dividend and $e$ is the fraction of the asset which has been nationalized. 
The stock grows at rate $\gamma$ per period. In the absence of asset expropriation, the firm issues dividends of $d(1+\gamma)^{t+k+1}$.

If the coup is successful, the expropriated asset gets restored forever. The dividend in period $t$ if the coup is successful is then $d(1+\gamma)^{t+k+1}$. If the coup is unsuccessful then the dividend is just $(1-e) d(1+\gamma)^{t+k+1}$. Whether the coup is successful or unsuccessful, we assume that the effects are permanent. If the coup succeeds, the dividends are restored in perpetuity and if the coup fails, the dividends permanently remain at the expropriated level.

The value of the stock at date $-k$ then is the discounted sum of dividends before the coup plus the probability of a successful coup times the discounted sum of dividends given a successful coup from the coup date onwards plus one minus the probability of a successful coup multiplied by the discounted sum of dividends given an unsuccessful coup:

$$
\begin{aligned}
S_{t}= & (1-e) \sum_{t=-k}^{-1} \beta^{t+k+1} d(1+\gamma)^{t+k+1}+ \\
& p_{-k} \sum_{t=0}^{\infty} \beta^{t+k+1} d(1+\gamma)^{t+k+1}+(1-e)\left(1-p_{-k}\right) \sum_{t=0}^{\infty} \beta^{t+k+1} d(1+\gamma)^{t+k+1}
\end{aligned}
$$

We can now derive an expression for the percentage change in the stock price:

$$
\frac{S_{-k+1}-S_{-k}}{S_{-k}}=\frac{e[\beta(1+\gamma)]^{k-1}\left[p_{-k+1}-p_{-k} \beta(1+\gamma)\right]+\gamma}{1+p_{-k} e[\beta(1+\gamma)]^{k}}
$$

Solving for the change in the probability of the coup between dates $k$ and $-k+1$, we get:

$$
p_{-k+1}-p_{-k}=\frac{1}{e[\beta(1+\gamma)]^{k-1}}\left[\frac{S_{-k+1}-S_{-k}}{S_{-k}}-\gamma\right]-p_{-k}[1-\beta(1+\gamma)(1+\Delta S)]
$$

The intuition for this expression can be captured by the following approximation (which is exact when $\beta(1+\gamma)(1+\Delta S)=1$ or when $\left.p_{-k}=0\right)$ : 


$$
p_{-k+1}-p_{-k} \approx \frac{1}{e[\beta(1+\gamma)]^{k-1}}\left[\frac{S_{-k+1}-S_{-k}}{S_{-k}}-\gamma\right]
$$

The change in the probability of the coup can be backed out from the abnormal stock return. The term in brackets is the difference between the stock price change and the normal rate of return. In other words, it is the stock's abnormal return. Therefore, from equation (11), we can interpret the change in the probability of a coup as an exposure adjusted and discounted abnormal return ${ }^{11}$.

\subsubsection{Numerical Evaluation}

We now numerically evaluate the model. We back out implicit changes in probabilities of a successful coup from an average authorization event for a company. We assume that $p_{-k}$ is close to zero ${ }^{12}$. Then, $\frac{S_{-k+1}-S_{-k}}{S_{-k}}-\gamma$ is just the estimated abnormal return which we take from Table V. For the sake of consistency, we choose the estimate from the time horizon with the highest t-statistic. We compute $k-1$ as the average number of days before the coup for a private authorization event. We assume $\beta$ to be 0.95 annually; however, since some of the events occur shortly before the coup, we do our computations in days rather than years and so we compute a daily equivalent for an annual $\beta . \gamma$ is computed as the average daily rate of return for the market (New York stock exchange index) in the estimation window. Finally, $e$ is the exposure of a company, as defined in the data section and Appendix B.

The cumulative change in probability from ex-ante authorizations in Guatemala is approximately 18\%. The cumulative change in probability for the Anglo-Iranian Oil Company was 29\%. Lastly, for Anaconda, the imputed change in probability is $6 \%$. On average, the mean change in probabily due to an authorization is substantial and similar across countries. Variations in the cumulative changes probabilty are therefore

\footnotetext{
${ }^{11}$ The fact that the change in the imputed probability is larger when the date of the coup is farther in the future is a consequence of stationarity of the discounted dividend stream (i.e. $\beta(1+\gamma)<1$ ).

${ }^{12}$ This assumption does not have a large effect our calibration. Note that if we assume that $p_{-k} \approx 0 \%$, then our simple formula holds. However, if we assume $p_{-k} \approx 100 \%$, then imputed probabilites change by at most $4 \%$.
} 
due to differing sets of events.

\section{Conclusion}

Covert operations organized and abetted by foreign governments have played a substantial role in the political and economic development of poorer countries around the world. We look at CIA-backed coups against governments which had nationalized a considerable amount of foreign investment. Using an event-study methodology, we find that private information regarding coup authorizations and planning by the U.S. government increased the stock prices of expropriated multinationals that stood to benefit from the regime change. The presence of these abnormal returns suggests that there were leaks from the CIA or others in the executive branch of government to asset traders or that government officials with access to this information themselves traded upon it. Consistent with theories of asset price determination under private information, this information took some time to be fully reflected in the stock price. Moreover, the evidence we find suggests that coup authorization information was only present in large, politically connected companies which were also highly exposed.

We find that coup authorizations, on net, contributed more to stock price rises of highly exposed and well connected companies than the coup events themselves. These price changes reflect sizeable shifts in beliefs about the probability of coup occurrence.

Our results are robust across countries, except Cuba, as well as to a variety of controls for alternate sources of information, including public events and newspaper articles. The anomalous results for Cuba are consistent with the information leaks and inadequate organization that surrounded that particular coup attempt. Our results are consistent with evidence in political science that US business interests exert disproportionate influence on foreign policy (Jacobs and Page, 2005), as well as historical

accounts which suggest that protecting U.S. foreign investments was a motivation 
for undertaking regime change (Kinzer, 2004). However, further empirical research is needed to uncover whether or not economic factors were decisive determinants of U.S. government decisions to covertly overthrow foreign governments. 


\section{References}

Abadie, A. and J. Gardeazabal. 2003. "The Economic Costs of Conflict: A Case Study of the Basque Country." The American Economic Review 93(1):113-132.

Allen, F., S. Morris and H.S. Shin. 2006. "Beauty Contests and Iterated Expectations in Asset Markets." Review of Financial Studies 19(3):719-752.

Andersen, T.G., T. Bollerslev, F.X. Diebold and C. Vega. 2003. "Micro Effects of Macro Announcements: Real-Time Price Discovery in Foreign Exchange." The American Economic Review 93(1):38-62.

Baklanoff, E.N. 1975. Expropriation of US investments in Cuba, Mexico, and Chile. New York: Praeger.

Campbell, JY, AW Lo and A. McKinley. N.d. "C., 1997. The Econometrics of Financial Markets.".

Chomsky, N. 1985. Turning the Tide: US Intervention in Central America and the Struggle for Peace. South End Press.

Constable, P. and A. Valenzuela. 1991. A Nation of Enemies: Chile Under Pinochet. WW Norton \& Co Inc.

Cullather, N. 2006. Secret History: The CIA's Classified Account of Its Operations in Guatemala, 1952-1954. Stanford University Press.

Della Vigna, S. and E. La Ferrara. 2007. "Detecting Illegal Arms Trade." NBER Working Paper .

Dunkerley, J. 1988. Power in the Isthmus: A Political History of Modern Central America. Verso.

Easterly, W., S. Satyanath and D. Berger. N.d. "Superpower Interventions and Their Consequences for Democracy." . Forthcoming. mimeograph.

Faccio, Mara. 2006. "Politically connected firms." The American economic review 96(1):369-386. 
Fisman, D., R. Fisman, J. Galef and R. Khurana. 2006. Estimating the value of connections to Vice-President Cheney. Technical report Working paper, Columbia University.

Fisman, R. 2001. "Estimating the Value of Political Connections." American Economic Review 91(4):1095-1102.

Gasiorowski, M.J. 1991. US Foreign Policy and the Shah: Building a Client State in Iran. Cornell University Press.

Gasiorowski, M.J. and M. Byrne. 2004. Mohammad Mosaddeq and the 1953 coup in Iran. Syracuse University Press, Syracuse.

Gibbs, D.N. 1991. The Political Economy of Third World Intervention: Mines, Money, and US Policy in the Congo Crisis. University Of Chicago Press.

Gleijeses, P. 1991. Shattered Hope: The Guatemalan Revolution and the United States, 1944-1954. Princeton University Press.

Gleijeses, P. 1995. "Ships in the Night: The CIA, the White House, and the Bay of Pigs." Journal of Latin American Studies 27(1):1-42.

Guidolin, M. and E. La Ferrara. 2007. "Diamonds Are Forever, Wars Are Not: Is Conflict Bad for Private Firms?" American Economic Review 97(5):1978-1993.

Guidolin, M. and E. La Ferrara. N.d. "The Economic Effects of Violent Conflict: Evidence from Asset Market Reactions." . Forthcoming.

Husain, A. 2005. "Covert Action and US Cold War Strategy in Cuba, 1961-62." Cold War History 5(1):23-53.

Immerman, R.H. 1980. "Guatemala as Cold War History." Political Science Quarterly 95(4):629-653.

Immerman, R.H. 1982. The CIA in Guatemala: The Foreign Policy of Intervention. University of Texas Press. 
Jacobs, L.R. and B.I. Page. 2005. "Who Influences US Foreign Policy?" American Political Science Review 99(1).

Jayachandran, S. 2006. "The Jeffords Effect*." The Journal of Law and Economics 49(2):397-425.

Johnson, L.K. 1989a. America's Secret Power: The CIA in a Democratic Society. Oxford University Press, USA.

Johnson, L.K. 1989b. "Covert Action and Accountability: Decision-Making for America's Secret Foreign Policy." International Studies Quarterly 33(1):81-109.

Jones, B.F. and B.A. Olken. 2005. "Do Leaders Matter? National Leadership and Growth Since World War II*." The Quarterly Journal of Economics 120(3):835864.

Kinzer, S. 2003. All the Shah's Men: An American Coup and the Roots of Middle East Terror. John Wiley \& Sons.

Kinzer, S. 2006. Overthrow: America's Century of Regime Change from Hawaii to Iraq. Times Books.

Knight?, B. 2007. "Are policy platforms capitalized into equity prices? Evidence from the Bush/Gore 2000 Presidential Election." Journal of Public Economics 91(12):389-409.

Kolko, G. 1988. Confronting the Third World: United States Foreign Policy, 19451980. Pantheon Books.

Kornbluh, P. 1998a. Bay of Pigs declassified: the secret CIA report on the invasion of Cuba. New York: The New Press.

Kornbluh, P. 1998b. "Chile and the United States: Declassified Documents Relating to the Military Coup, September 11, 1973.".

Kornbluh, P. 2003. The Pinochet file: a declassified dossier on atrocity and accountability. New Press, New York. 
Mahoney, J. 2002. The Legacies of Liberalism: Path Dependence and Political Regimes in Central America. Johns Hopkins University Press.

Meulbroek, L. 1992. "An empirical analysis of illegal insider trading." Journal of Finance 47(5):1661-1699.

Mood, A.M., F.A. Graybill and D.C. Boes. 1974. "Introduction to the theory of statistics.".

Morris, S. and HS Shin. 2003. "Global Games: Theory and Applications, forthcoming in Advances in Economics and Econometrics." the Eighth World Congress (M. Dewatripont, L. Hansen and S. Turnovsky, eds.), Cambridge University Press .

on Latin America, North American Congress. 1972. New Chile. New York: .

Petersen, M.A. N.d. "Estimating Standard Errors in Finance Panel Data Sets: Comparing Approaches." . Forthcoming. Mimeograph.

Schlesinger, S. and S. Kinzer. 2005. Bitter fruit: the story of the American coup in Guatemala. Harvard University.

Sigmund, P.E. 1977. The overthrow of Allende and the politics of Chile, 1964-1976. Pittsburgh: University of Pittsburgh Press.

Sigmund, P.E. 1993. The United States and Democracy in Chile. Johns Hopkins University Press.

Smith, P.H. 2000. Talons of the Eagle: Dynamics of US-Latin American Relations. Oxford University Press, USA.

Snowberg, E., J. Wolfers and E. Zitzewitz. 2007. "Partisan Impacts on the Economy: Evidence From Prediction Markets and Close Elections*." The Quarterly Journal of Economics 122(2):807-829.

Steenland, K. 1974. "The Coup in Chile." Latin American Perspectives 1(2):9-29.

Vandenbroucke, L. 1984. "The Anatomy of a Failure: The Decision to Land at the Bay of Pigs." Political Science Quarterly 99(3):471-91. 
Weiner, T. 2007. Legacy of Ashes: The History of the CIA. Doubleday Press.

Westad, O.A. 2005. The Global Cold War: Third World Interventions and the Making of Our Times. Cambridge University Press. 


\section{Appendix A:Historical Background on each Coup}

\section{$9.1 \quad$ Iran 1953}

"Anglo-Iranian Rises on News of Mossadegh's Fall" - August 20, 1953

New York Times Headline.

In 1951, Muhammed Mossadegh campaigned for prime minister on a platform of ending British ownership of Iranian oil. The Iranian parliament (the Majlis) had passed a measure supporting nationalization on March 25, 1951. Mossadegh was elected Prime Minister by the Majlis on April 28, 1951. His assumption of power on April 28 was followed quickly by a nationalization of Anglo-Iranian oil assets on May 1, 1951. Initially commanding a great deal of popular support, Mossadegh threatened the power of the Shah. The Shah dismissed Mossadegh on July 18th, 1952, only to reinstate him 5 days later after a barrage of popular protest. However, support for Mossadegh fell by the middle of 1953. The Truman administration had attempted to broker a deal between the British and the Iranian government. With the advent of the Eisenhower administration, however, the U.S. government's interesting in overthrowing Mossadegh increased. In late 1952, the British MI6 found an ear receptive to the idea of overthrowing Mossadegh in Allen Dulles, and final coup plans were joinly approved by the CIA and MI6 on June 18, 1953.

Churchill approved the coup plan on July 1, 1953, with Eisenhower's endorsement following 10 days later. The United States and the United Kingdom spent hundreds of thousands of dollars on lobbying politicians and hiring crowds of demonstrators (Gasiorowiski and Byrne, 2004). They also convinced the Shah to dismiss Mossadegh and assume power directly. On August the 16th, the coup began, but failed owing to logistical and planning problems. However, anti-Mossadegh protests and violence over the next few days culminated in Mossadegh's overthrow on August 19, 1953. 


\subsection{Guatemala 1954}

"The overthrow of the Communist-dominated government of Guatemala, while causing a cessation of shipments from that country for period of about 3 weeks, was a decidedly favorable development which will have far-reaching effects in the future."- 1954 United Fruit Shareholder's Report

Guatemala has been historically marked by a high degree of political and economic inequality (Mahoney 2002, Dunkerley 1985). The center-left Arevalo regime that came to power in 1945, following the first free elections in the country, immediately provoked the anger of the coffee planters by striking down the most repressive of the labor regulations. The 1951 successor government, led by Jacobo Arbenz, had a policy platform centered around a comprehensive land reform and modernization plan. The leftist government thus threatened both the domestic coffee landlords as well as the United Fruit company, which owned over $40 \%$ of Guatemala's land, along with all the banana processing plants, virtually all of the shipping ports, and most of the railroads in the country (Gleijeses, 1991).

On June 17, 1952, the agrarian reform bill was passed, and redistribution began on August 7 of the same year. The land reform bill also encouraged peasant land occupations, which were violently suppressed by landowners. On December 12, 1952, workers at the Tiquisate plantation filed for 55,000 acres to be expropriated from United Fruit under the agrarian reform bill. United Fruit petitioned the Supreme Court, which demanded a stay on all land confiscation and redistribution. In response, the Arbenz-dominated congress voted to impeach the Supreme Court. On February 25, 1953, the Guatemalan government expropriated 234,000 more acres from United Fruit, and subsequently another 173,000 acres in the following year.

The United States foreign policy establishment, prodded by United Fruit's intense public relations and lobbying effort, reacted to the 1952 implementaion of the Arbenz land reform as evidence that the country was becoming communist. Allen Dulles, then Deputy Director, promoted the coup vigorously to DCI(Director of Central Intelli- 
gence) Walter Bedell Smith and Truman (Schlesinger and Kinzer, 2005). On August 18, 1952, Operation PBFortune was approved by Bedell Smith, only to be halted on October 8, 1952, as potential leaks of the coup plot were discovered. However, with the advent of the Eisenhower government, Allen Dulles was promoted to DCI, and approved a new plan to overthrow Arbenz on December 9, 1953, and full approval was given by Eisenhower given on April 19th, 1954.

The coup was launched on June 19, 1954 when US-backed Castillo Armas and his force of 150 troops invaded Guatemala from Honduras. At first the coup was unsuccesful. After 9 days, on June 28, 1954 the Arbenz government capitulated (Immerman, 1981).

\subsection{Cuba 1961}

On January 1, 1959, the Cuban dictator, Fulgencio Batista, fled Cuba to the Dominican Republic. On January 3rd, the new government was set up and on January 8 of 1959, Fidel Castro's march through Havana signalled that the Cuban revolution was a fait-accompli.

Following an initially lukewarm reaction from the United States, and a friendly U.S. tour by Castro in April of the same year, relations chilled quickly when Castro obtained 100 advisors from the USSR and expropriated all foreign (largely U.S.) landholdings in May, 1959. Covert plans to overthrow Castro began in the fall of 1959, modelled on the Guatemalan intervention and with many of the same CIA officers involved. On March 17, 1960, Eisenhower gave presidential approval to the CIA's plan, and later authorized 13 million dollars towards the overthrow of the Castro regime. The date of the coup was set for August 19, 1960. The plan involved a small group of trained Cuban exiles who would invade, establish a beachhead, and draw support in the countryside, eventually deposing Castro. Publically, the U.S. responded to the increased closeness of the Castro government with the Soviet Union by progressively increasing economic sanctions and diplomatically ostracizing the new Cuban govern- 
ment. In retaliation, the Cuban government nationalized U.S. held assets in Cuba starting on August 5, 1960, and continuing in October of the same year.

When Kennedy assumed power in January 1961, he authorized continuation of the CIA plan on January 30, 1961, after extensive deliberation with advisors. The Bay of Pigs invasion failed to overthrow the Cuban government, generating ample speculation as to why. Firstly, there were regular leaks of the plans to the press. The CIA had also falsely predicted a popular anti-Castro uprising following the invasion. In addition, the U.S. operation against Cuba was characterized by a large number of miscommunications and logistical errors (Giejses, 1995; Wiener, 2007; Prados, 2006), culminating in Kennedy's decision not to provide air support to the exile invasion force (Kornbluh, 1998; Vandenbroucke, 1984). After 3 days of fighting, the last of the invaders were captured by the Cuban military. Relations between Cuba and the United States further deteriorated, with the CIA conspiring regularly to assassinate Castro in the decades following the coup attempt.

\subsection{Chile 1971-73}

"Anaconda was one of those on the plus side, rising $\frac{7}{8}$ to $22 \frac{7}{8}$. Its strength was attributed partly to the revolt yesterday in Chile against the Marxist government, which, in 1971, expropriated the holdings of Anaconda and other U.S. companies." .- September 12, 1973 quote from the Wall Street Journal

The Allende government that narrowly won elections on September 4, 1970 had already overcome a long series of U.S. and domestic obstacles, beginning in 1958 with Allende's first run for president. Through the Alliance for Progress program, the United States had been heavily involved with Chilean domestic politics, trying to deflate the left-wing FRAP alliance (Sigmund, 1989) and more generally create a positive example of a free-market, democratic economy in Latin America. The Christian Democrats, backed by the U.S., handily won the 1964 municipal elections, as 
well as the 1965 senate elections. The September 4, 1970 elections were sufficiently close that Allende's ratification as president required a congressional vote on October 24, 1970, a fact that the first U.S. plan tried to exploit.

Copper was by far the most important industry in Chile. Within 2 months of assuming office, Allende had proposed nationalizing the mines, and on July 11, 1971, the Chilean legislature approved nationalization. While domestic pressure for "Chileanization" of the large copper mines was omnipresent, the Christian Democratics favored a majority shareholder stake for the government, together with generous compensation, and retention of both foreign management and rights of control. This was in contrast to the position of Allende's FRAP, which demanded outright nationalization and a much smaller compensation package. In particular, on September 28, 1971, the government declared that the copper multinationals had been making "excess profits" since 1946, and deducted this from the compensation package.

The U.S. began plotting for a coup even before Allende formally assumed power, with Nixon authorizing an anti-Allende plan on September 15, 1970. Coup planning and funding authoriziation after this was delegated to the 40 Committee, which was set up in the wake of the Bay of Pigs failure in order to operate as the mediating body between the upper eschelons of the executive branch of the US government and the CIA. The CIA and the State Department began two tracks in the fall of 1970; Track 1, which was involved public political support for Allende's domestic opponents, and Track 2 which involved covert political operations against the government. Track 1 ended with Allende's ratification by the legislature, but "Track 2 never really ended"13.

On January 28, 1971, the 40 committee appropriated $\$ 1.2$ million for the overthrow of the Allende regime. This was followed by an additional $\$ 1.4$ million on October 26, 1972. Finally, on August 21, 1973, a few months after Allende managed to strengthen his electoral support in the March 4, 1973 municipal elections, the 40 committee allocated $\$ 1$ million to overthrow Allende. While the true extent of CIA

\footnotetext{
${ }^{13}$ CIA officer Tom Karamessines, cited in (Weiner, pg. 315).
} 
participation in the 1973 coup that deposed Allende is unknown, it is known that they supported and had knowledge of Pinochet's coup plan (Kornbluh, 2003). On September 11, 1973, the Allende government was toppled in a military coup.

\section{Appendix B: Data Appendix on Company Ex- posures}

In Appendix B, we compute exposure ratios of multinational corporate assets to nationalization by foreign governments. In later years, compensation requests were made by companies to the US government. Where this data is available, we use it. In the case of Iran and Guatemala, we reconstruct asset exposures using available valuations of sub-assets held by the multinational in the country.

\subsection{Anglo-Iranian Oil Company (Iran)}

After the coup, the Anglo-Iranian Oil Company (AIOC) received 40\% of Iran's oil assets, while the rest went to a consortium of French and American companies. AIOC was also paid 182 million pounds via a premium on their oil price, and 57.4 million directly from the Iranian government and the other consortium members. While we do not know exactly how much the oil assets are worth, we can calculate the expected compensation from what AIOC asked from the consortium. Bamberg (1982, pg 501) writes that Fraser, the negotiator for AIOC, asked for 530 million pounds from Iran together with 280 million pounds from the consortium.

Unfortunately, the New York Times historical records from "Bonds and Shares on the London Market" did not contain the number of shares outstanding. Nevertheless, we obtained annual share volumes from Luiten Van Zanden et al. (2007), which reports 20,137,500 shares outstanding for Anglo-Iranian from 1930 to 1953. Concomitant with the change to British Petroleum, the company split the stock by a factor of 5 . The mean price from january to may of 1950 is 130.81 pounds sterling. This generates 
a market value of 2.48 billion pounds sterling.

\subsection{United Fruit Company (Guatemala)}

United Fruit experienced 3 episodes of land expropriation under Decree 900 of the Arbenz government. The first, in March 1953, was the only one for which compensation was formally demanded via the State department. United Fruit asked for "more than 15 million"14, which Gleijeses found was 19.35 million, in compensation for roughly 234,000 acres $^{15}$ valued at $\$ 83.3$ each. The Guatemalan government instead offered $\$ 610,000$ in agrarian bonds, paying 3\% interest over 25 years, which equals $\$ 1.27$ million in total. The total land owned by UFCO in guatemala is 550,000 acres ${ }^{16}$, including improved and unimproved lands. Assuming a constant per-acre valuation, we can calculate the value of all of United Fruits land. If we do not distinguish between improved and unimproved lands, a lower bound on the total valuation is $\$ 550,000 \times$ $83.3=\$ 45.8$ million

The other major asset of United Fruit in Guatemala was their ownership of railroads, which was also threatened by the Arbenz government, even though no railroads were nationalized. Part of the threat came from modernization projects (e.g. an Atlantic highway) that would threaten the profitability of the railroad as a monopoly on longdistance transit. The 1954 shareholders report for United fruit lists that the total value of railways and tramways is $\$ 29,541,405$. United Fruit had 185.17 miles of railways in Guatemala, out of 1,486.31 miles total, and 43.78 miles of tramways out of 181.49 total. Thus, the fraction of their railways in Guatemala is 0.124, and the fraction of tramways is 0.241 . Thus, the total rail and tramway fraction in Guatemala is 0.137 . Assuming a constant value of rail and tram across countries, we get that the value of rail and tram assets in Guatemala is $\$ 29,541,405$. Putting these two pieces of information together, we get that the total exposure of United Fruit in Guatemala was $\$ 45.8$ million plus $\$ 29.5$ million, totalling $\$ 75.3$ million dollars.

\footnotetext{
${ }^{14}$ UFCO 1954 shareholders report

${ }^{15}$ FRUS:Foreign Relations, 1952-1954, vol. IV, pp. 1056-1057 (Document 13).

${ }^{16}$ Foreign Relations of the United States
} 


\subsection{Chilean Companies}

We calculate of the Chilean companies from Baklanoff (1975), who reports the amounts claimed by each of the copper companies. For the other companies reported as having filed expropriation claims, but with no amount of claim given, we use the NACLA "New Chile" book, which gives the value of investment in 1970 for most foreign companies and US parent percentage equity, to calculate exposure. The NACLA numbers are obtained from a variety of sources (NACLA lists both the business press, e.g. Forbes, and official Department of Commerce publications, among others), and it is not possible to determine where each company's investment in Chile comes from. We cross-check the NACLA numbers with the Congressional testimony (ITT's executives testified as to the worth of their expropriated investments), and find, reassuringly, that ITT's investment in Chile is listed at $\$ 153$ million by both sources.

\subsection{Cuban Companies}

We obtain the value of expropriated assets from Baklanoff (1975), who provides a table of the top 10 claims filed by Cuban companies to Congress in 1972, obtained from Congressional records. In order to account for inflation, we calculate the mean inflation rate between 1959 and 1972, 3\% from the BLS CPI index, as use it to calculate the value of the assets in 1959 . 


\begin{tabular}{|c|c|c|c|c|c|c|}
\hline Project & Country & Year & $\begin{array}{c}\text { Planning Docs } \\
\text { Declassified }\end{array}$ & Description & Coup & Exprop. \\
\hline Ajax & Iran & 1953 & Yes & Coup against Mossadeq & Yes & Yes \\
\hline FU/Belt & Chile & $1970-73$ & Yes & Coup against Allende & Yes & Yes \\
\hline Bloodstone & Germany & 1946 & No & Recruitment of Nazis & No & DK \\
\hline Brushfire & US & 1955 & Yes & Propaganda at Universities & No & No \\
\hline Camelot & Chile & $1960 \mathrm{~s}$ & No & Funded Anthro. Research & No & DK \\
\hline ST/Circus & Tibet & 1955 & No & Trained Tibetan Rebels & Yes & No \\
\hline Democracy & Nicaragua & 1985 & No & Anti-Sandinista Operations & No & DK \\
\hline IA/Feature & Angola & 1975 & No & Supported Savimbi & No & Yes \\
\hline Fiend & Albania & 1949 & No & Insurgency & Yes & DK \\
\hline Fortune/PB/Success & Guatemala & $1952-54$ & Yes & Coup Against Arbenz & Yes & Yes \\
\hline PM/Forget & All over & $1950 \mathrm{~s}$ & No & Don’t Know & DK & DK \\
\hline Haik & Indonesia & $1956 / 57$ & No & Military Support for Rebels & Yes & Yes \\
\hline HardNose & Vietnam & 1965 & No & Disrupt Viet Cong Supplies & No & No \\
\hline Momentum & Laos & 1959 & No & Trained Hmong in Laos & No & No \\
\hline Mongoose & Cuba & 1961 & Yes & Post-Bay of Pigs Operations & No & Yes \\
\hline Opera & France & 1951 & No & Electoral Manipulations & No & DK \\
\hline Paper & China & 1951 & No & Invasion from Burma & No & No \\
\hline Stole & N. Korea & $1950 / 51$ & No & Sabotage & No & No \\
\hline Tiger & Syria & 1956 & Yes & Assassination Attempts & No & DK \\
\hline Washtub & Guatemala & 1954 & Yes & Anti-Arbenz Propaganda & No & Yes \\
\hline Wizard & Congo & 1960 & No & Lumumba Assassination & Yes & Yes \\
\hline Zapata & Cuba & $1960-61$ & Yes & Bay of Pigs & Yes & Yes \\
\hline
\end{tabular}

Notes: (1.) Project is the name of the operation, (2.) Country is the target country of the operation, (3.) Year is the year when the operation was carried out, (4.) Planning documents records yes if the planning documents are publicly available, (5.) Description is a description of the operation, (6.) Coup is recorded as yes if a coup was planned as part of the operation and no otherwise, and (7.) Exprop. refers to whether or not the regime nationalized (or expropriated) property from multinational firms operating within the country, (8.) DK denotes don't know. 
TABLE II: COMPANY SELECTION

\begin{tabular}{|c|c|c|c|c|c|c|}
\hline Company Name & $\begin{array}{l}\text { Coup } \\
\text { Country }\end{array}$ & $\begin{array}{l}\text { Expropriation } \\
\text { Description }\end{array}$ & Source & $\begin{array}{l}\text { Exprop. } \\
\text { Value }\end{array}$ & $\begin{array}{l}\text { Total } \\
\text { Value }\end{array}$ & $\begin{array}{l}\text { Exposure } \\
\text { Ratio }\end{array}$ \\
\hline Anglo-Iranian Co. & Iran & Oil & Bamberg & 810 & 2,607 & 0.311 \\
\hline United Fruit Co. & Guatemala & Land & Gleijses & 75 & 441 & 0.171 \\
\hline American Sugar Refining Co. & Cuba & Land & Baklanoff & 49 & 52 & 0.940 \\
\hline International Tel \& Teleg. & Cuba & Tel./Radio & Baklanoff & 79 & 231 & 0.344 \\
\hline Standard Oil Co. of NJ & Cuba & Oil & Baklanoff & 43 & 11,670 & 0.004 \\
\hline Texas Co. & Cuba & Oil & Baklanoff & 30 & 3,614 & 0.008 \\
\hline United Fruit Co. & Cuba & Land & Baklanoff & 52 & 385 & 0.134 \\
\hline Anaconda Co. & Chile & Mines & Baklanoff & 320 & 1,054 & 0.303 \\
\hline Anglo Lautaro Nitrate & Chile & Mines & Nacla & Bought out & 23 & \\
\hline General Motors Corp. & Chile & Car Factory & Nacla & 0.08 & 22,800 & 0.000 \\
\hline General Tire \& Rubber Co. & Chile & Rubber Plant & Nacla & 6.66 & 474 & 0.014 \\
\hline International Tel \& Teleg. & Chile & Tel./Radio & Baklanoff & 153 & 3,030 & 0.073 \\
\hline Kennecott Copper Corp. & Chile & Mines & Baklanoff & 217 & 1,558 & 0.139 \\
\hline
\end{tabular}

Notes I: (1.) Company name refers to the name of the company at the time of the coup, (2.) Coup country is the country where the coup or coup attempt was made, (3.) Expropriation description lists the types of assets expropriated, (4.) Source lists the source of information on the expropriations, (4.) Baklanoff, Bamburg, Gleijses, and Nacla are authors of books which list exporpropriations, (5.) Exprop. value list the nominal amount of the value of the expropriation in currency units of the estimation window year, (6.) All monetary values are expressed in US dollars with the exception of the Anglo Iranian Oil Company which is expressed in pounds, (6.) Total value lists the average stock price for the company in current currency units during the estimation window, (7.) Exposure ratio is the ratio of the value of expropriated assets to the total market value of the company.

Notes II: Many companies have changed their names. Anglo-Iranian is now called British Petroleum. The United Fruit Company is now called Chiquita Brands International. The Standard Oil Company of New Jersey is now called ExxonMobil. Texas Company is now called Texaco. International Telephone and Telegraph Corporation is now called ITT Corporation. American Sugar Refining Co. is now called Domino Foods, Inc. 
TABLE III: Authorization Event Selection

\begin{tabular}{|c|c|c|c|}
\hline Date & Country & Description & Good \\
\hline June 18,1953 & Iran & CIA/British Intelligence Both Approve Coup & $\mathrm{Y}$ \\
\hline July 1,1953 & Iran & British Prime Minister Approves Coup & Y \\
\hline July 11,1953 & Iran & President Eisenhower Appoves Coup & $\mathrm{Y}$ \\
\hline August 18, 1952 & Guatemala & DCIA Approves PBFortune (Coup to Overthrow Arbenz) & $\mathrm{Y}$ \\
\hline October 8, 1952 & Guatemala & PBFortune Halted & $\mathrm{N}$ \\
\hline December 9, 1953 & Guatemala & DCIA Approves PBSuccess (Coup to Overthrow Arbenz) & $\mathrm{Y}$ \\
\hline April 19, 1954 & Guatemala & Full Approval Given to PBSuccess & $\mathrm{Y}$ \\
\hline March 17, 1960 & Cuba & Eisenhower Approves Plan to Overthrow Castro & $\mathrm{Y}$ \\
\hline August 19, 1960 & Cuba & Eisenhower Approves \$13 Million to Overthrow Castro & $\mathrm{Y}$ \\
\hline January 30, 1961 & Cuba & Kennedy Authorizes Continuing Bay of Pigs Op & $\mathrm{Y}$ \\
\hline September 15,1970 & Chile & Nixon Authorizes Anti-Allende Plan (Incl. Poss. Coup) & $\mathrm{Y}$ \\
\hline January 28, 1971 & Chile & 40 Committee Appropriates $\$ 1.2$ Million & $\mathrm{Y}$ \\
\hline October 26, 1972 & Chile & 40 Committee Appropriates $\$ 1.4$ Million & $\mathrm{Y}$ \\
\hline August 21,1973 & Chile & 40 Committee Appropriates \$1 Million & $\mathrm{Y}$ \\
\hline
\end{tabular}

Notes: (1.) Date is the date of the event, (2.) Country is the target country of the coup attempt, (3.) Description gives a brief description of the event, (4.) Good is coded as $\mathrm{Y}$ if the event should raise the share value of the company and $\mathrm{N}$ if the event should lower the share value of the company. 
TABLE IVA: Public Event Selection

\begin{tabular}{|c|c|c|c|}
\hline Date & Country & Description & Good \\
\hline March 25, 1951 & Iran & Iranian Parliament Backs Oil Nationalization & $\mathrm{N}$ \\
\hline April 28, 1951 & Iran & Prime Minister of Iran Quits and Mossadeq Elected & $\mathrm{N}$ \\
\hline July 18, 1952 & Iran & Ghavam Replaces Mossadeq as Prime Minister & $\mathrm{Y}$ \\
\hline July 23, 1952 & Iran & Mossadeq Comes Back As Prime Minister & $\mathrm{N}$ \\
\hline August 4, 1953 & Iran & Mossadeq Asks For Parliament to be Dissolved & $\mathrm{N}$ \\
\hline November 11,1950 & Guatemala & Arbenz Elected & $\mathrm{N}$ \\
\hline June 17,1952 & Guatemala & Arbenz Enacts Agrarian Reform Bill & $\mathrm{N}$ \\
\hline August 7, 1952 & Guatemala & Distribution of Land Under Agraian Reform Bill Begins & $\mathrm{N}$ \\
\hline December 12,1952 & Guatemala & Workers File for Expropriation of 55,000 Acres From UF & $\mathrm{N}$ \\
\hline February 5, 1953 & Guatemala & Congress Impeaches Court to Fasten Reform & $\mathrm{N}$ \\
\hline February 24, 1954 & Guatemala & Guatemala Confiscates 234,000 Acres & $\mathrm{N}$ \\
\hline January 1,1959 & Cuba & Castro Comes to Power in Cuban Revolution & $\mathrm{N}$ \\
\hline August 5, 1960 & Cuba & Cuba Nationalizes Electricity, Oil, Telephone, Sugar & $\mathrm{N}$ \\
\hline October 12,1960 & Cuba & Cuba Nationalizes Sugar, Beer, Liquor, Soap & $\mathrm{N}$ \\
\hline October 24,1960 & Cuba & Cuba Nationalizes 166 More Businesses & $\mathrm{N}$ \\
\hline September 4, 1970 & Chile & Allende Wins Election & $\mathrm{N}$ \\
\hline October 24, 1970 & Chile & Legislature Votes for Allende & $\mathrm{N}$ \\
\hline December 21, 1970 & Chile & Allende Proposes Mine Nationalization & $\mathrm{N}$ \\
\hline July 11,1971 & Chile & Ammendment Allowing Nationalization of Copper & $\mathrm{N}$ \\
\hline September 28, 1971 & Chile & Excess Profits Subtracted From Nationalization Comp. & $\mathrm{N}$ \\
\hline September 29, 1971 & Chile & Chitelco (owned by ITT) Nationalized & $\mathrm{N}$ \\
\hline May 12, 1972 & Chile & ITT Expropriation Requested by Allende & $\mathrm{N}$ \\
\hline March 4, 1973 & Chile & Allende's Party Get $43 \%$ of Vote in Elections & $\mathrm{N}$ \\
\hline
\end{tabular}

Notes: (1.) Date is the date of the event, (2.) Country is the target country of the coup attempt, (3.) Description gives a brief description of the event, (4.) Good is coded as $\mathrm{Y}$ if the event should raise the share value of the company and $\mathrm{N}$ if the event should lower the share value of the company. 
TABLE IVB: Coup Dates

\begin{tabular}{clcc}
\hline \hline & \multicolumn{1}{c}{ Date } & Country & Successful \\
\cline { 2 - 4 } Begin & August 15, 1953 & Iran & Yes \\
End & August 20,1953 & & \\
& & & \\
Begin & June 19,1954 & Guatemala & Yes \\
End & June 28, 1954 & & \\
& & & \\
Begin & April 15, 1961 & Cuba & \\
End & April 20,1961 & & \\
& & & Yes \\
Begin & September 11, 1973 & Chile & \\
End & September 11, 1973 & & \\
\hline \hline
\end{tabular}

Notes: (1.) Date lists the begin and end dates of coups, (2.) Country lists the country where the coup or coup attempt took place, (3.) Successful records whether or not the coup achieved its objectives in overthrowing the government in question. 
TABLE V

Main Effects - Cumulative Abnormal Returns

\begin{tabular}{|c|c|c|c|c|c|c|c|}
\hline & & $(0,0)$ & $(0,3)$ & $(0,6)$ & $(0,9)$ & $(0,12)$ & $(0,15)$ \\
\hline \multirow{2}{*}{ All } & In-Sample & $\begin{array}{c}0.0018 \\
(0.0024) \\
N=5053\end{array}$ & $\begin{array}{c}0.0171 \\
(0.0066)^{* * *} \\
\mathrm{~N}=5053\end{array}$ & $\begin{array}{c}0.0184 \\
(0.0101)^{*} \\
\mathrm{~N}=5053\end{array}$ & $\begin{array}{c}0.0263 \\
(0.0132)^{* *} \\
\mathrm{~N}=5053\end{array}$ & $\begin{array}{c}0.0312 \\
(0.0147)^{* *} \\
\mathrm{~N}=5053\end{array}$ & $\begin{array}{c}0.0303 \\
(0.0186) \\
\mathrm{N}=5053\end{array}$ \\
\hline & Out-Sample & $\begin{array}{c}0.0017 \\
(0.0024) \\
N=14\end{array}$ & $\begin{array}{c}0.0178 \\
(0.0078)^{* *} \\
\mathrm{~N}=56\end{array}$ & $\begin{array}{c}0.0204 \\
(0.0099)^{* *} \\
\mathrm{~N}=98\end{array}$ & $\begin{array}{c}0.0261 \\
(0.0137)^{*} \\
\mathrm{~N}=140\end{array}$ & $\begin{array}{c}0.0339 \\
(0.0155)^{* *} \\
\mathrm{~N}=182\end{array}$ & $\begin{array}{c}0.0313 \\
(0.0170)^{*} \\
\mathrm{~N}=208\end{array}$ \\
\hline \multirow{2}{*}{ Top 3} & In-Sample & $\begin{array}{c}0.0019 \\
(0.0025) \\
N=11\end{array}$ & $\begin{array}{c}0.0234 \\
(0.0089)^{* * *} \\
\mathrm{~N}=44\end{array}$ & $\begin{array}{c}0.0261 \\
(0.0112)^{* * *} \\
\mathrm{~N}=77\end{array}$ & $\begin{array}{r}0.0281 \\
(0.0149)^{*} \\
\mathrm{~N}=110\end{array}$ & $\begin{array}{c}0.0389 \\
(0.0171)^{* *} \\
\mathrm{~N}=143\end{array}$ & $\begin{array}{c}0.0442 \\
(0.0197)^{* *} \\
\mathrm{~N}=160\end{array}$ \\
\hline & Out-Sample & $\begin{array}{c}0.0017 \\
(0.0028) \\
N=4203\end{array}$ & $\begin{array}{c}0.0218 \\
(0.0079)^{* * *} \\
\mathrm{~N}=4203\end{array}$ & $\begin{array}{c}0.0224 \\
(0.0110)^{* *} \\
\mathrm{~N}=4203\end{array}$ & $\begin{array}{c}0.0269 \\
(0.0152)^{*} \\
\mathrm{~N}=4203\end{array}$ & $\begin{array}{c}0.0339 \\
(0.0166)^{* *} \\
\mathrm{~N}=4203\end{array}$ & $\begin{array}{c}0.0405 \\
(0.0209)^{*} \\
\mathrm{~N}=4203\end{array}$ \\
\hline Chile & In-Sample & $\begin{array}{l}-0.0047 \\
(0.0052) \\
N=1039\end{array}$ & $\begin{array}{c}0.0177 \\
(0.0197) \\
N=1039\end{array}$ & $\begin{array}{c}0.0075 \\
(0.0252) \\
N=1039\end{array}$ & $\begin{array}{c}0.0199 \\
(0.0355) \\
N=1039\end{array}$ & $\begin{array}{c}0.0244 \\
(0.0370) \\
\mathrm{N}=1039\end{array}$ & $\begin{array}{c}0.0332 \\
(0.0446) \\
N=1039\end{array}$ \\
\hline Cuba & In-Sample & $\begin{array}{c}0.0018 \\
(0.0043) \\
N=850\end{array}$ & $\begin{array}{c}0.0001 \\
(0.0089) \\
\mathrm{N}=850\end{array}$ & $\begin{array}{c}0.0035 \\
(0.0243) \\
\mathrm{N}=850\end{array}$ & $\begin{array}{c}0.0242 \\
(0.0265) \\
N=850\end{array}$ & $\begin{array}{c}0.0218 \\
(0.0315) \\
N=850\end{array}$ & $\begin{array}{c}-0.0044 \\
(0.0397) \\
N=850\end{array}$ \\
\hline Guat. & In-Sample & $\begin{array}{c}0.0068 \\
(0.0032)^{* *} \\
\mathrm{~N}=2352\end{array}$ & $\begin{array}{c}0.0244 \\
(0.0081)^{* * *} \\
\mathrm{~N}=2352\end{array}$ & $\begin{array}{c}0.0309 \\
(0.0130)^{* * *} \\
\mathrm{~N}=2352\end{array}$ & $\begin{array}{c}0.0224 \\
(0.0165) \\
N=2352\end{array}$ & $\begin{array}{c}0.0320 \\
(0.0186)^{*} \\
\mathrm{~N}=2352\end{array}$ & $\begin{array}{c}0.0306 \\
(0.0244) \\
N=2352\end{array}$ \\
\hline Iran & In-Sample & $\begin{array}{c}0.0035 \\
(0.0034) \\
\mathrm{N}=812\end{array}$ & $\begin{array}{c}0.0236 \\
(0.0064)^{* * *} \\
\mathrm{~N}=812\end{array}$ & $\begin{array}{c}0.0307 \\
(0.0139)^{* *} \\
\mathrm{~N}=812\end{array}$ & $\begin{array}{c}0.0447 \\
(0.0166)^{* * *} \\
\mathrm{~N}=812\end{array}$ & $\begin{array}{c}0.0540 \\
(0.0211)^{* * *} \\
\mathrm{~N}=812\end{array}$ & $\begin{array}{c}0.0763 \\
(0.0287)^{* * *} \\
\mathrm{~N}=812\end{array}$ \\
\hline
\end{tabular}

Notes: (1.) All multi-country regressions control for an interaction of a country dummy with the NYSE, (2.) Regressions control for the NYSE index, (3.) Regressions use robust standard errors, (4.) All dates where a company changed its name or changed its outstanding shares by more than 5\% were dropped, (5.) One day price changes greater than 50\% in magnitude were dropped, (6.) Out-sample rows compute abnormal returns using the "out of sample" method and In-Sample rows compute abnormal returns using the "in sample" regression method, (7.) Column numbers at the top in parentheses denote the number of days before and after the authorizations which are included as part of the dummy variable for the authorization event. 
TABLE VI

Public Information Controls

\begin{tabular}{|c|c|c|c|c|c|}
\hline & Public Info & NY Times & $\begin{array}{c}\text { No } \\
\text { NY Times }\end{array}$ & $\begin{array}{c}\text { No } \\
\text { Public Info }\end{array}$ & $\begin{array}{l}\text { Public and } \\
\text { NY Times }\end{array}$ \\
\hline \multirow[t]{3}{*}{ All } & 0.0171 & 0.0176 & 0.0244 & 0.0171 & 0.0175 \\
\hline & $(0.0066) * * *$ & $(0.0066) * * *$ & $(0.0102)^{* * *}$ & $(0.0066) * * *$ & $(0.0066)^{* * *}$ \\
\hline & $\mathrm{N}=5053$ & $\mathrm{~N}=4084$ & $\mathrm{~N}=747$ & $\mathrm{~N}=5032$ & $\mathrm{~N}=4084$ \\
\hline \multirow[t]{3}{*}{ Chile } & 0.0177 & 0.0177 & 0.0629 & 0.0176 & 0.0177 \\
\hline & $(0.0197)$ & $(0.0198)$ & $(0.0161)^{* * *}$ & $(0.0197)$ & $(0.0198)$ \\
\hline & $\mathrm{N}=1039$ & $\mathrm{~N}=1024$ & $\mathrm{~N}=203$ & $\mathrm{~N}=1030$ & $\mathrm{~N}=1024$ \\
\hline \multirow[t]{3}{*}{ Cuba } & 0.0000 & 0.0007 & 0.0173 & -0.0002 & 0.0006 \\
\hline & $(0.0089)$ & $(0.0088)$ & $(0.0149)^{*}$ & $(0.0089)$ & $(0.0088)$ \\
\hline & $\mathrm{N}=850$ & $\mathrm{~N}=804$ & $\mathrm{~N}=44$ & $\mathrm{~N}=846$ & $\mathrm{~N}=804$ \\
\hline \multirow[t]{3}{*}{ Guat. } & 0.0244 & 0.0255 & 0.0118 & 0.0244 & 0.0255 \\
\hline & $(0.0081)^{* * *}$ & $(0.0081)^{* * *}$ & $(0.0119)$ & $(0.0081)^{* * *}$ & $(0.0081)^{* * *}$ \\
\hline & $\mathrm{N}=2352$ & $\mathrm{~N}=1472$ & $\mathrm{~N}=485$ & $\mathrm{~N}=2346$ & $\mathrm{~N}=1472$ \\
\hline \multirow[t]{3}{*}{ Iran } & 0.0235 & 0.0231 & 0.0000 & 0.0237 & 0.0231 \\
\hline & $(0.0064) * * *$ & $(0.0065)^{* * *}$ & 0.0000 & $(0.0064) * * *$ & $(0.0066)^{* * *}$ \\
\hline & $\mathrm{N}=812$ & $\mathrm{~N}=784$ & $\mathrm{~N}=15$ & $\mathrm{~N}=810$ & $\mathrm{~N}=784$ \\
\hline
\end{tabular}

Notes: (1.) Estimates are on (0,3) day returns, (2.) All multi-country regressions control for an interaction of a country dummy with the NYSE, (3.) Regressions control for the NYSE index, (4.) Regressions use robust standard errors, (5.) All dates where a company changed its name or changed its outstanding shares by more than $5 \%$ were dropped, (6.) One day price changes greater than $50 \%$ in magnitude were dropped, (7.) Public regressions control for a four day dummy variable for time periods starting with public information days, (8.) NY Times regressions control for number of NY Times articles mentioning the country on that day, (9.) "No Public Info" and "No NY Times" regressions drop all observations where public information or NY Times respectively are positive. 
TABLE VII

Robustness

\begin{tabular}{lccccccc}
\hline \hline & Raw & Extended & Country & Industry & Trend & NYSE & Industry \\
& Returns & Sample & Portfolios & Controls & Controls & $\begin{array}{c}\text { Placebo } \\
\text { Placebo }\end{array}$ \\
\hline All & 0.0196 & -0.0018 & 0.0169 & 0.0166 & 0.0210 & 0.0036 & 0.0011 \\
& 2.4929 & -0.4197 & 2.4181 & 2.4501 & 2.5670 & 1.3473 & 0.3016 \\
& 5077 & 13640 & 5053 & 5053 & 5053 & 5101 & 5101 \\
Top 3 & 0.0233 & -0.0013 & 0.0228 & 0.0216 & 0.0241 & 0.0017 & -0.0003 \\
& 2.4410 & -0.2219 & 2.7790 & 2.6713 & 2.5176 & 0.0008 & -0.0787 \\
& 4227 & 9384 & 4203 & 4203 & 4203 & 4247 & 4247 \\
Chile & 0.0257 & -0.0088 & 0.0195 & 0.0175 & 0.0244 & 0.0068 & 0.0004 \\
& 1.0614 & -1.2042 & 0.9514 & 0.8653 & 1.0728 & 0.0016 & 0.1178 \\
& 1039 & 6220 & 1039 & 1039 & 1039 & 1039 & 1039 \\
& & & & & & & \\
Guat. & 0.0202 & 0.0244 & 0.0242 & 0.0244 & 0.0270 & -0.0051 & -0.0004 \\
& 2.1794 & 3.0271 & 3.1229 & 3.0184 & 2.9212 & 0.0008 & -0.0406 \\
& 2352 & 2352 & 2352 & 2352 & 2352 & 2357 & 2357 \\
& & & & & & & \\
Iran & 0.0243 & 0.0236 & 0.0247 & 0.0233 & 0.0137 & 0.0046 & -0.0011 \\
& 3.8698 & 3.6672 & 2.9884 & 3.7286 & 1.4106 & 0.0012 & -0.3428 \\
& 836 & 812 & 812 & 812 & 812 & 851 & 851 \\
& & & & & & & \\
Cuba & 0.0056 & -0.0029 & -0.0041 & -0.0019 & 0.0088 & 0.0097 & 0.0063 \\
& 0.5531 & -0.5655 & -0.4009 & -0.2035 & 0.6403 & 0.0012 & 1.4644 \\
& 850 & 4256 & 850 & 850 & 850 & 854 & 854
\end{tabular}

Notes: (1.) Estimates are on (0,3) returns, (2.) Multi-country regressions control for an interaction of a country dummy with the NYSE, (3.) Regressions control for the NYSE index, (4.) Regressions use clustered standard errors, (5.) Dates where a company changed its name or changed its outstanding shares by more than $5 \%$ were dropped, (6.) One day price changes greater than $50 \%$ in magnitude were dropped, (7.) Raw returns do not control for the NYSE, (8.) Month clusters cluster on month for a given year and country, (9.) Industry controls control for 3-digit industry returns, (10.) Country portfolios redefines our treatment companies as a portfolio of all companies operating within a country which were mentioned by name in CIA dpcuments and which had over $15 \%$ of company assets in the coup country, (11.) Trend controls control for trends by creating an additional dummy in an 20 day symmetric window around the authorization days, (12.) Extended sample includes a wider selection of less highly exposed companies (aall companies in Table II), (13.) NYSE and Industry Placebos replace company returns with the NYSE index and the industry index resp 
TABLE VIII

Time-Shifted Placebos

\begin{tabular}{|c|c|c|c|c|c|}
\hline Date & Abnormal Ret & Date & Abnormal Ret & Date & Abnormal Ret \\
\hline-30 & $\begin{array}{c}0.0037 \\
(0.0069) \\
\mathrm{N}=5054\end{array}$ & & & 30 & $\begin{array}{c}0.0068 \\
(0.0069) \\
\mathrm{N}=5025\end{array}$ \\
\hline-20 & $\begin{array}{c}0.0017 \\
(0.0083) \\
\mathrm{N}=5054\end{array}$ & & & 20 & $\begin{array}{l}-0.0030 \\
(0.0087) \\
\mathrm{N}=5035\end{array}$ \\
\hline-15 & $\begin{array}{l}-0.0044 \\
(0.0069) \\
N=5054\end{array}$ & & & 15 & $\begin{array}{l}-0.0010 \\
(0.0104) \\
N=5040\end{array}$ \\
\hline-10 & $\begin{array}{l}-0.0002 \\
(0.0094) \\
N=5054\end{array}$ & & & 10 & $\begin{array}{l}-0.0010 \\
(0.0078) \\
N=5045\end{array}$ \\
\hline-5 & $\begin{array}{l}-0.0003 \\
(0.0096) \\
N=5054\end{array}$ & & & 5 & $\begin{array}{c}0.0064 \\
(0.0101) \\
N=5050\end{array}$ \\
\hline & & 0 & $\begin{array}{c}0.0171 \\
(0.0066) * * * \\
\mathrm{~N}=5053\end{array}$ & & \\
\hline
\end{tabular}

Notes: (1.) Regressions are pooled across countries, (2.) Regressions control for the interaction of a country dummy with the NYSE, (2.) All single country regressions control for the NYSE index, (3.) All standard errors are robust, (4.) All dates where a company changed its name or changed its outstanding shares by more than 5\% were dropped, (5.) All one day price changes greater than $50 \%$ in magnitude were dropped, (6.) Authorization event days are shifted forward by number of days in date column. 
TABLE IX

Coup Event

\begin{tabular}{|c|c|c|c|}
\hline & Coup Window & First Day of Coup & First Day of New Govt \\
\hline \multirow[t]{3}{*}{ ALL } & 0.0503 & 0.0223 & 0.0346 \\
\hline & $(0.0207)^{* * *}$ & $(0.0074)^{* * *}$ & $(0.0073)^{* * *}$ \\
\hline & $\mathrm{N}=5053$ & $\mathrm{~N}=5053$ & $\mathrm{~N}=5053$ \\
\hline \multirow[t]{3}{*}{ Chile } & 0.0464 & 0.0464 & 0.0464 \\
\hline & $(0.0198)^{* * *}$ & $(0.0198)^{* * *}$ & $(0.0198)^{* * *}$ \\
\hline & $\mathrm{N}=1039$ & $\mathrm{~N}=1039$ & $\mathrm{~N}=1039$ \\
\hline \multirow[t]{3}{*}{ Cuba } & 0.0548 & 0.0272 & 0.0339 \\
\hline & $(0.0480)$ & $(0.0160)^{*}$ & $(0.0160)^{* *}$ \\
\hline & $\mathrm{N}=850$ & $\mathrm{~N}=850$ & $\mathrm{~N}=850$ \\
\hline \multirow[t]{3}{*}{ Guatemala } & -0.0119 & -0.0013 & 0.0373 \\
\hline & $(0.0436)$ & $(0.0107)$ & $(0.0106)^{* * *}$ \\
\hline & $\mathrm{N}=2352$ & $\mathrm{~N}=2352$ & $\mathrm{~N}=2352$ \\
\hline \multirow[t]{3}{*}{ Iran } & 0.0857 & 0.0168 & 0.0206 \\
\hline & $(0.0474)^{*}$ & $(0.0157)$ & $(0.0157)$ \\
\hline & $\mathrm{N}=812$ & $\mathrm{~N}=812$ & $\mathrm{~N}=812$ \\
\hline
\end{tabular}

Notes: (1.) All multi-country regressions control for an interaction of a country dummy with the NYSE, (2.) All single country regressions control for the NYSE index, (3.) Due to small sample sizes, only multi-country regressions have clustered standard errors, (4.) All dates where a company changed its name or changed its outstanding shares by more than $5 \%$ were dropped, (5.) All one day price changes greater than $50 \%$ in magnitude were dropped, (6.) Coup window estimates are obtained from regressions of returns on a dummy variable which takes on a value of one during the coup window, then are multipled by the length of the coup window. (7.) First day of coup regressions are regressions of returns an a dummy variable for the first day of the coup, (8.) First day of new government regressions are regressions of returns on a dummy variable for the first day of the new regime after the end of the coup. In the case of Cuba this is the first day after the end of the invasion. 
TABLE X

Bernoulli Test (Sign Test)

\begin{tabular}{|c|c|c|c|c|c|c|c|}
\hline & $\begin{array}{c}\text { Number } \\
\text { Events }\end{array}$ & $\begin{array}{c}\text { Number } \\
\text { Above } \\
\text { Median }\end{array}$ & $\begin{array}{c}\text { P-Value: } \\
\text { True }\end{array}$ & $\begin{array}{l}\text { P-Value: } \\
\text { Simulated }\end{array}$ & $\begin{array}{c}\text { Number } \\
\text { Above } \\
90 \text { th }\end{array}$ & $\begin{array}{c}\text { P-Value: } \\
\text { True }\end{array}$ & $\begin{array}{l}\text { P-Value: } \\
\text { Simulated }\end{array}$ \\
\hline Chile & 4 & 3 & 0.6250 & $X$ & 1 & 0.6878 & $X$ \\
\hline Cuba & 3 & 1 & 1.0000 & $X$ & 0 & 1.0000 & $X$ \\
\hline Guatemala & 4 & 4 & 0.1250 & $X$ & 3 & 0.0074 & $X$ \\
\hline Iran & 3 & 3 & 0.2500 & $X$ & 2 & 0.0560 & $X$ \\
\hline 3 Country & 11 & 9 & 0.0654 & $X$ & 6 & 0.0006 & $X$ \\
\hline 4 Country & 14 & 11 & 0.0574 & $X$ & 6 & 0.0030 & $X$ \\
\hline
\end{tabular}

(1.) Number above median is the number of 4-day events above the median abnormal return in the estimation window (2.) P-Value: True reports the associated P-Value using the Binomial Distribution to give the probability of having at least X number of events above the median or Y-X below the median out of Y total events, (3.) P-Value: Simulated reports the p-value for a simulated placebo distribution of the abnormal return counts above a cutoff (median or 90th percentile respectively), (4.) Number above the 90th percentile reports the number of 4-day events above the 90th percentile of the abnormal return distribution in the estimation window, (5.) 3 country refers to the 3 country sample excluding Cuba and 4 country refers to the full sample. 
TABLE XI

Uniform Test (Rank Test)

\begin{tabular}{|c|c|c|c|c|c|c|}
\hline & $\begin{array}{c}\text { Number } \\
\text { Events }\end{array}$ & $\begin{array}{c}\text { Mean Raw } \\
\text { Rank }\end{array}$ & $\begin{array}{c}\text { Total } \\
\text { Number of } \\
\text { Dates } \\
\end{array}$ & $\begin{array}{c}\text { Mean } \\
\text { Percentage } \\
\text { Rank } \\
\end{array}$ & $\begin{array}{c}\text { P-Value: } \\
\text { True } \\
\end{array}$ & $\begin{array}{l}\text { P-Value: } \\
\text { Simulated }\end{array}$ \\
\hline Chile & 4 & 25.25 & 59 & 0.57 & 0.6398 & 0.6060 \\
\hline Cuba & 3 & 31.33 & 62 & 0.49 & 0.9550 & 0.9290 \\
\hline Guatemala & 4 & 9.75 & 71 & 0.86 & 0.0082 & 0.0140 \\
\hline Iran & 3 & 9.00 & 65 & 0.86 & 0.0247 & 0.0310 \\
\hline 3 Country & 11 & N/A & N/A & 0.76 & 0.0034 & 0.0040 \\
\hline 4 Country & 14 & N/A & N/A & 0.70 & 0.0009 & 0.0080 \\
\hline
\end{tabular}

(1.) Mean raw rank refers to the average raw rank of abnormal returns for events relative to the estimation window in the country or group of countries, (2.) total number of dates refers to the number of 4-day return observations in the estimation window, (3.) Mean percentage rank is the average percentage rank of abnormal returns for events relative to the estimation window, (4.) P-Value: True reports the p-value of the average rank for the sum of $\mathrm{K}$ unit uniforms where $\mathrm{K}$ is the number of events, (5.) P-Value: Simulated reports the p-value for a simulated placebo distribution of the abnormal return ranks, (6.) 3 country refers to the 3 country sample excluding Cuba and 4 country refers to the full sample. 
TABLE XII

Relative Gains From Coup and Authorization Events

\begin{tabular}{|c|c|c|c|c|c|}
\hline & $\begin{array}{c}\text { Per Event } \\
\text { Authorization } \\
\text { Event Gain } \\
\end{array}$ & $\begin{array}{c}\text { Total Gain from } \\
\text { Authorization } \\
\text { Events }\end{array}$ & $\begin{array}{c}\text { Gain From Coup } \\
\text { Event }\end{array}$ & $\begin{array}{l}\text { Total Gain from } \\
\text { Coup }\end{array}$ & $\begin{array}{l}\text { Relative Gain } \\
\text { From Auth. } \\
\text { Events } \\
\end{array}$ \\
\hline All & 0.0312 & 0.0966 & 0.0346 & 0.1345 & 0.7363 \\
\hline Chile & 0.0303 & 0.1268 & 0.0464 & 0.1791 & 0.7321 \\
\hline Cuba & 0.0154 & 0.0469 & 0.0369 & 0.0855 & 0.5597 \\
\hline Guatemala & 0.0313 & 0.0636 & 0.0373 & 0.1033 & 0.6303 \\
\hline Iran & 0.0540 & 0.1709 & 0.0206 & 0.1950 & 0.8924 \\
\hline
\end{tabular}

Notes: (1.) Per event authorization event gain is the cumulative abnormal return over a thirteen day period for a company in a country estimated individually, (2.) Total gains from authorization events is one plus the abnormal return to the power of the number of net events; in the case of Guatemala, the number of net events is 2 out of total 4 events since one event was a coup abortion and thus counted as negative, (3.) The gain from the coup event is the estimated abnormal returns from the first day of the new government after the end of the coup, (4.) The total gain from the coup is the cumulative gain from the authorization events plus the gain from the coup itself, (5.) The relative gain from authorization events is the share of the total gain from the coup (including pre-coup stock market rises) due to authorization events. 
TABLE XIII

Calibration

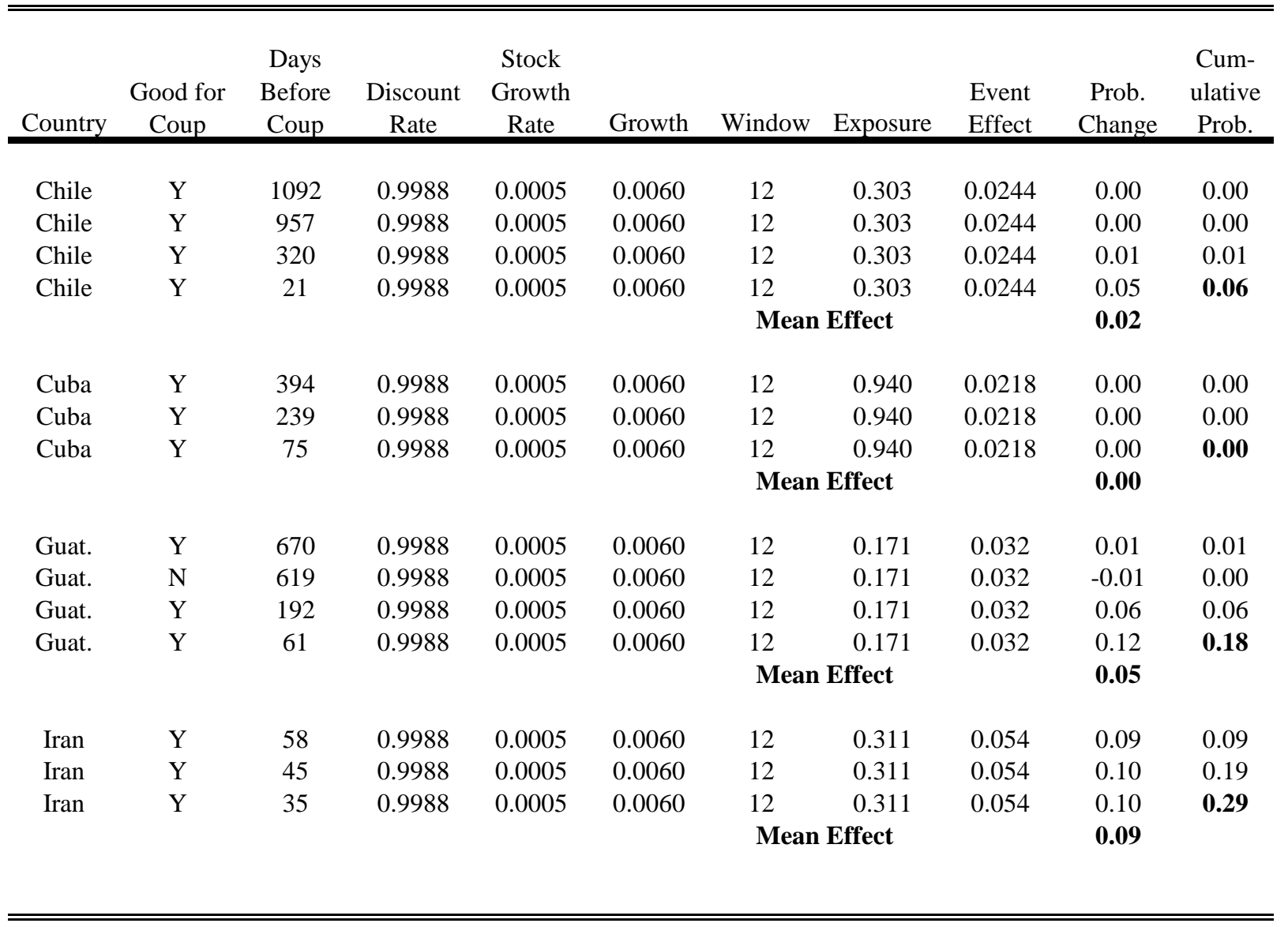

Notes: (1.) This table shows the inputs and outputs of a calibrated model of asset price determination with a time-varying prob. of a coup, (2.) Country is the country where the coup attempt took place, (3.) Good for Coup is Y for authorizations and N for deauthorizations, (4.) Days before coup is the number of trading days before the coup, (5.) Discount factors are daily equivalents based upon an annual rate of 0.95 , (6.) Growth rate is the average daily growth rate of the stock in the 3 year period before and including the estimation window; stock growth rate is the corresponding 7-day average growth rate, (7.) Window is the number of days with the maximum t-stat for our Main Effects Table (Table V), (8.) Exposure is the percentage of company assets in the coup country, (9.) Event effect is the estimate of the impact of the authorization event window with the highest t-stat for each country, (10.) Probability change is the calibrated change in probability due to an authorization event; cumulative prob. is the cumulative net change in probability in the country, and (11.) Mean effect is the mean calibrated change in probability across events in a country. 


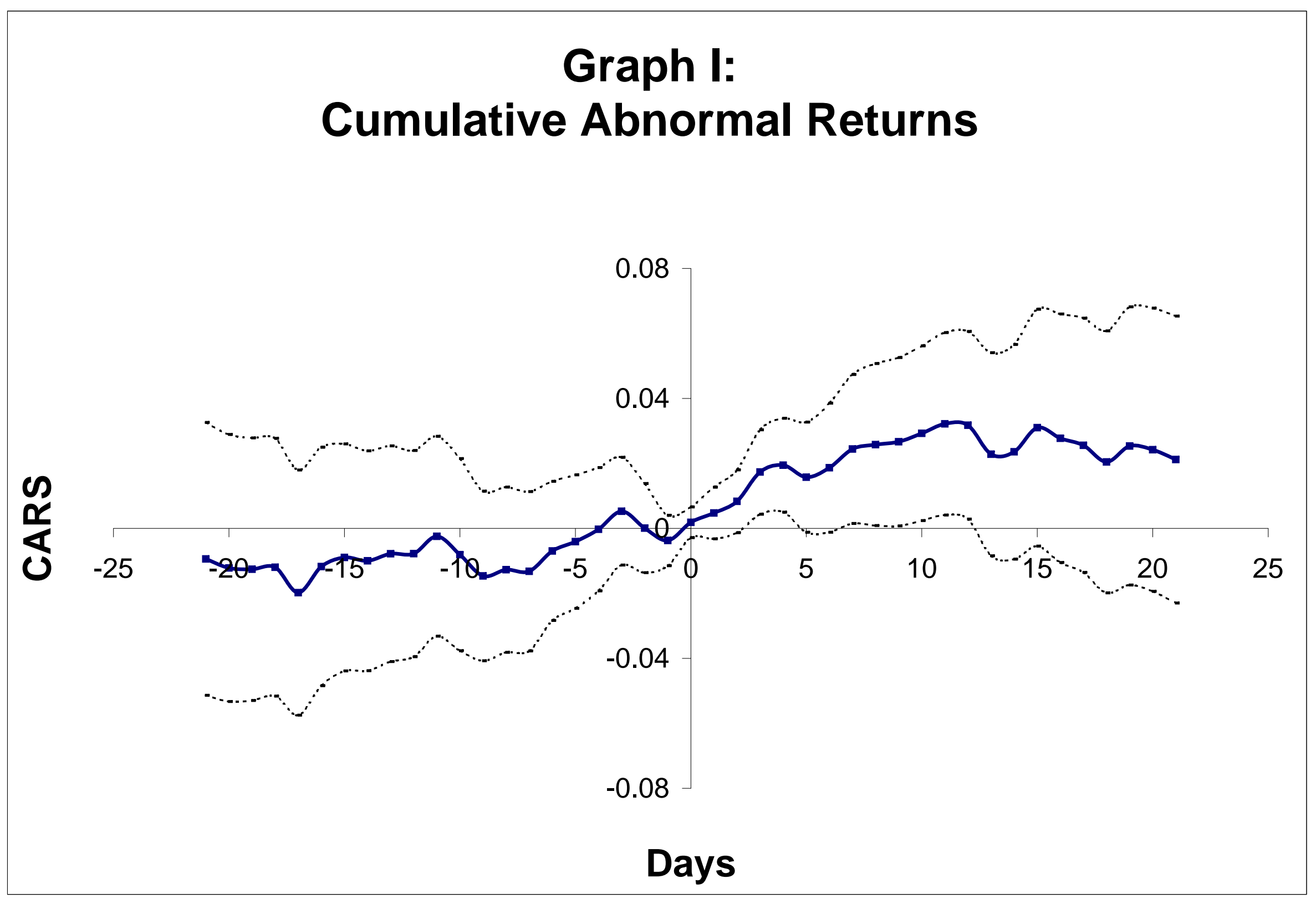




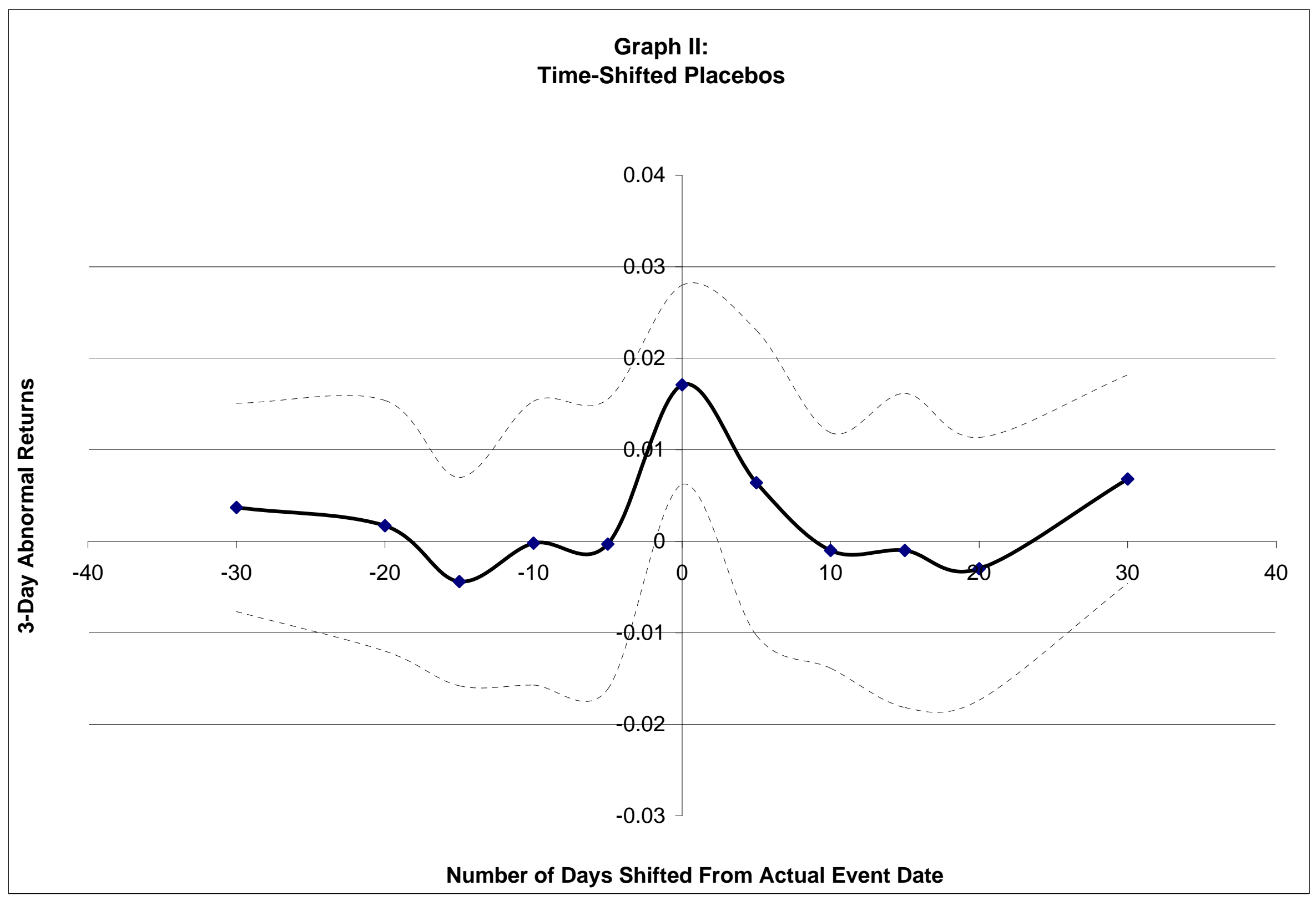




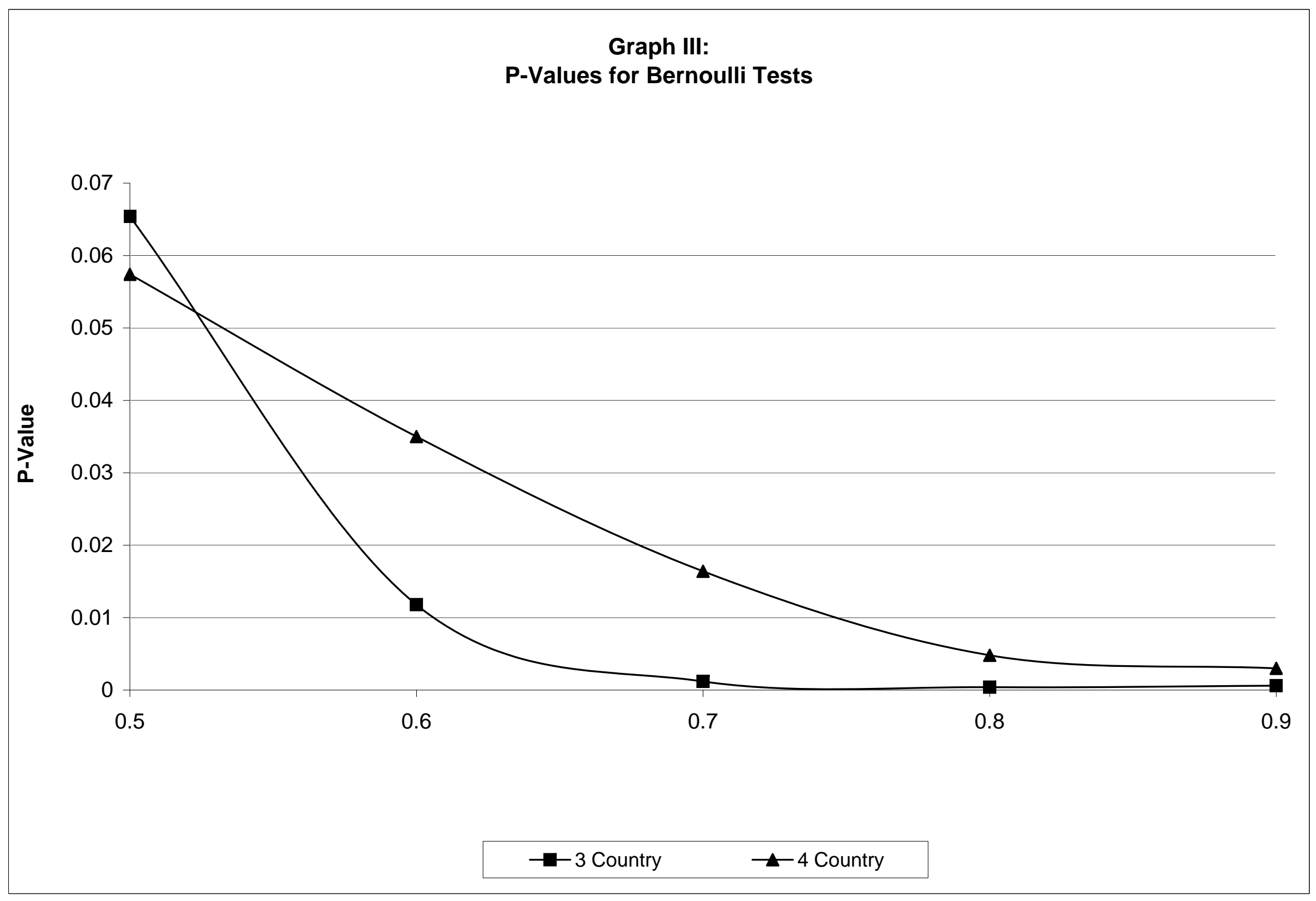




\section{Graph IV}

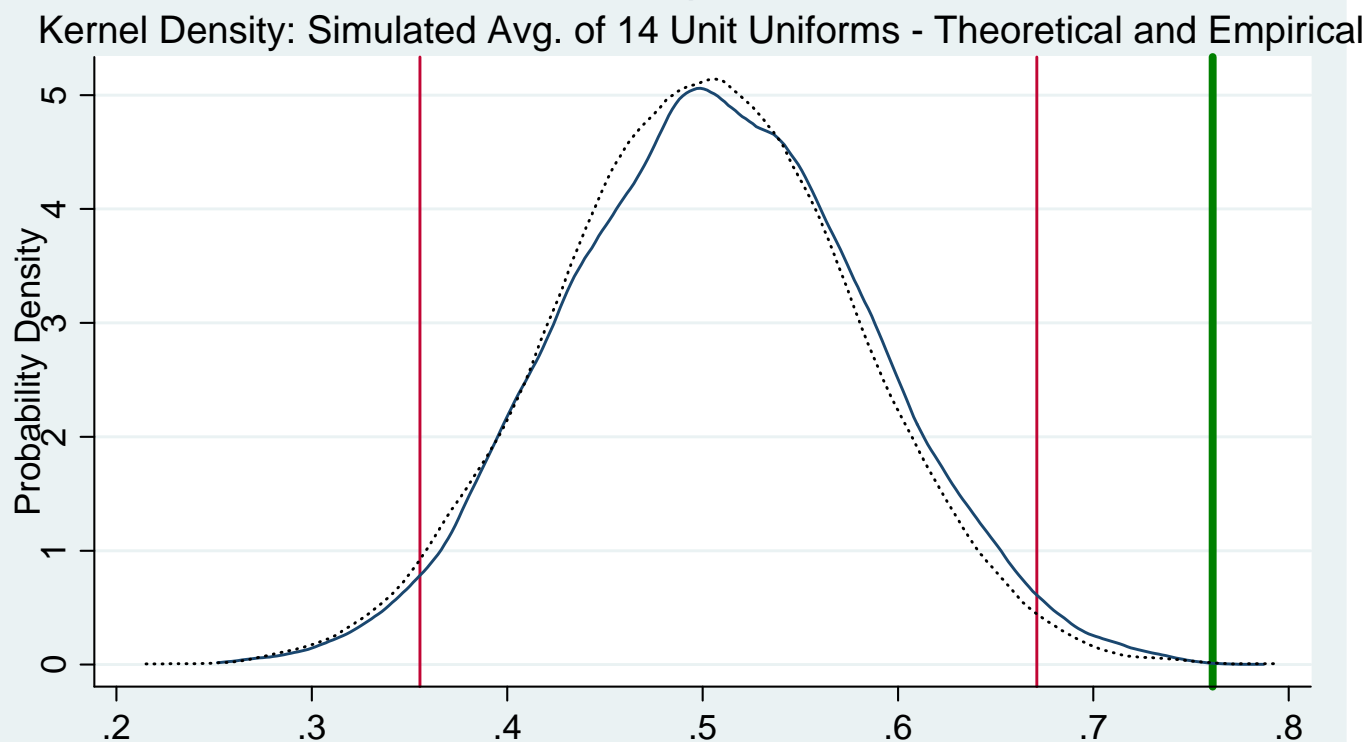

Note: Red lines indicate 2.5 and 97.5 pctiles and thick green line indicates avg. event pctile 